\title{
HOW ECONOMISTS ENTERED THE 'NUMBERS GAME': MEASURING DISCRIMINATION IN THE US COURTROOMS, 1971-1989
}

Cléo Chassonnery-Zaïgouche ${ }^{1}$

\section{Abstract}

The paper explores why and how economists entered the courtrooms as expert witnesses in employment discrimination cases in the US. The main sources are published legal decisions. I analyze the courts' and economists' discourses on the use of a specific method, multiple regression analysis in relation to litigation history, academic debates, and the institutional settings of expertise within the courts. I first show how the early reception of the method in the late 1970s did not involve systematic rejection from the courts but rather a large amount of skepticism. I then illustrate how economic theory underlying the method was progressively introduced in the "judicial tool-kit" and how the debates in the courtrooms relates to the debates in academia in the 1980s. Finally, by 1989, practical and ethical questions regarding the institutional settings of experts' testimony took center stage, reflecting the increasing professionalization of forensic economics.

\footnotetext{
${ }^{1}$ CRASSH, University of Cambridge, email: cc2006@cam.ac.uk
} 


\section{INTRODUCTION ${ }^{2}$}

“What do you mean by natural laws? Not any laws about wages?” In Stasny v. Southern Bell Tel. \& Tel. Co. (1978), District Judge MacMillan rejected the results of a multiple regression analysis (MRA) brought to the court by the defendant's expert, the economist James Gwartney. The judge blamed the expert witness for "getting [the court] back to Rousseau['s natural laws]" (quoted in Fienberg 1989, p.152). What Gwartney was in fact trying to explain was the standard use of "natural log" to represent wage data. The misunderstanding was not only a matter of bad hearing, as log and law sound similar: In the published decision, the court dismissed the fundamental assumptions of the method as "intellectually questionable and not grounded in any solid evidence" (Stasny, p.323). In the game of winning an argument in court, economists had to learn that their scientific credentials would not confer a decisive advantage.

In employment discrimination cases, the "numbers game" was understood by journalists as one of "apply[ing] [...] microeconomic and computer techniques to a mountain of statistical data". ${ }^{3}$ The objective of the "game" was to produce quantitative evidence of discrimination. Translated into numerical or graphical exhibits, this evidence often accompanied a written or oral testimony by an expert witness. Hired by one or both parties, experts were generally crossexamined by the other party's lawyer assisted by his own expert, and by the judge. The confrontation of two opposing experts and the examination of their testimonies by the court

\footnotetext{
${ }^{2}$ I am indebted to Steve Medema, Christina Laskaridis, and Béatrice Cherrier for their crucial help in the making of this paper. I also thank François Allisson, Federico Brandmayr, Nicolas Chachereau, Jessica Clement, Annie Lou Cot, Maxime Desmarais-Tremblay, Jean-Baptiste Fleury, David Gindis, Dan Hirschman, Dorian Jullien, Harro Maas, Magdalena Malecka, Alain Marciano, Guillaume Noblet and John Singleton, as well as the reviewers, for their helpful comments on various versions of the paper. I would like to thank Tiago Mata for access to The Fortune issue, Francine Blau for comments on the Vuyanich trial and James Gwartney for answering some of my questions by email. All errors remained mine.

3 "Expert Witness: Economists Turn Data into Testimony" by Penny Singer, The New York Times, January 19, 1986. The "numbers game" is an expression used by quantitative sociologists (see Jenkins \& Kroll-Smith 1996) and economists, e.g. Kaye (1982b), to refer to the practices of expert witnessing based on quantitative analysis.
} 
define the adversarial process in the US system (by contrast with the European use of experts appointed by the court and not by the parties). Starting in the 1970s, the "numbers game" intensified throughout the following decades and became a large part of Forensic economics, a subfield of economics institutionalized in the late 1980s.

From the 1970s until the 1980s, MRA was economists' primary tool for measuring discrimination. It did so by decomposing the observed differences in mean economic outcomes (wages, promotion rates) between two demographic groups (women and men, minority and majority) into a portion explained by mean differences in human capital characteristics (such as education or experience) and an unexplained residual. This residual was attributed to discriminatory practices. The technique was based on the application of a "Mincer earning function": a single-equation that models wage as a function of schooling and experience. ${ }^{4}$ Using the "unexplained" wage gap between demographic groups as a measure of discrimination became standard practice in the 1970s as micro-econometric techniques reshaped the field of labor economics both in academia and in policy evaluation contexts.

This article describes how the use of MRA was received in U.S. courtrooms and how economists made sense of judges' and lawyers' understanding of their practices. More specifically, it seeks to unpack how, over fifteen years, judges' reactions evolved from blunt dismissal, as exemplified by MacMillan's reaction, to widespread and largely unchallenged use. By the early 1980s, the use of MRA was considered standard practice in employment discrimination litigation (Finkelstein 1980, Fisher 1980, Fienberg 1982). Ten years after the Stasny case, labor economists Ashenfelter and Oaxaca celebrated how "economists entered the

\footnotetext{
${ }^{4}$ This approach became known as the "Oaxaca-Blinder" method in the $1990 \mathrm{~s}$, in reference to two separate papers Ronald Oaxaca (1973) and Alan Blinder (1973) published when both were researchers at the Industrial Relations Section at Princeton University. For an analytical history of the "Mincer equation" see Heckman et al. (2003). For reviews of the "Oaxaca-Blinder" method and main results, see Cain (1986), Oaxaca (2007) and Blau \& Kahn (2017). See also Teixeira (2007) on Jacob Mincer's contributions to labor economics, and especially his collaboration with Gary Becker.
} 
courtroom" through the dissemination of Gary Becker's model of discrimination (Ashenfelter \& Oaxaca 1987, p.321). Their paper notified the economics profession that "[i]n practice, the economists' view has made considerable headway in the courts", a view initially thought as “irrelevant and hopelessly complex for legal minds" (Ashenfelter \& Oaxaca 1987, p.323).

The standard narrative by which economists explain this transformation relies on the epistemic power of economics to conquer unscientific judges' minds. ${ }^{5}$ My goal here is to challenge this linear model of "influence" of ideas. I argue that the rise of economists as expert witnesses is better captured as a diffusion of a set of tools that meets a demand from courts. In the present case, the rise of economists as expert witnesses in discrimination cases is captured by observing the diffusion and reception of practices based on the use of micro-econometric tools. In doing so, this article shifts the focus away from a uniform application and impact of human capital theory or the influence of a homogeneous "economist' view". ${ }^{6}$ Influence is thus investigated by observing how practices of economist expert witness were recorded in legal decisions. Such framework allows the coexistence of diverging interpretations of economists' expertise in court. It eventually locates the development of MRA in a wider legal, intellectual and technical context from the early 1970s until the end of the 1980s.

I show, first, that the dissemination of MRA was both constrained and fostered by the changing US court system. The use of quantitative methods in the legal arena was hardly new in the 1970s (Golan 1999). Yet, it was boosted with the enactment of a new litigation doctrine in 1971,

\footnotetext{
${ }^{5}$ For an example of this vision of the history of Forensic economics, see e.g. the first issue of the Journal of Forensic Economics and the symposium in the Journal of Economic Perspectives entitled "Economists as Expert Witnesses" (1999, 13(2)). I call this narrative "empirical imperialism". Just as in the case of "economics imperialism", it is historically a narrative built by the actors themselves, before becoming a label to condemn or criticize the practice of frontier crossing (Chassonnery-Zaïgouche 2018).

${ }^{6}$ My narrative goes in the same direction as recent histories of human capital in practice as a diffusion of a set of tools at the U.S. department of labor (Breslau 1997), in education policies in the U.S. (Holden and Biddle 2017), and in international organizations such as the World Bank (Teixeira 2017) or the OECD (Schmelzer 2016) as well as via textbooks (Teixeira 2018).
} 
namely "disparate impact" (also named after the court case, viz. the Griggs doctrine). This doctrine implied indirect evidence of discrimination can be brought to courts, without evidence of intent to discriminate. Hence, quantitative methods demonstrating broad disparities between groups' outcomes could then be examined by courts. Some years after Griggs, legal rules defining what type of expertise was acceptable in courts underwent a crucial change with the enactment of Federal Rules of Evidences (FRE) in 1975. The rules de facto replaced the "Frye test" (1923) which was loosely based on the "general acceptance" principle - an expert testimony is valid if the methods used are generally accepted within its field of origin. Rule 701 and 702 of the FRE defined experts' role as helping the trier of fact by producing an opinion derived from specialized knowledge. ${ }^{7}$

The same year as the revision of the FRE, a widely quoted note published in the influential Harvard Law Review advocated for a systematic use of MRA in employment discrimination cases (Note 1975). ${ }^{8}$ As employers' motivations were not directly observable, the note argued, "human capital theory" suggested the "formula" at the basis of their decisions (Note 1975, p. 408, note 90). In the following years, three Supreme Court decisions on statistics in 1977 have been seen as "opening the floodgates" of experts testimony based on quantitative analysis in the courts (Fienberg 1989, p.88, p.93). ${ }^{9}$ These decisions parralleled the explosion of tort litigation (Berrey, Nelson \& Nielsen 2017, p.38-50), producing, in the case of employment discrimination, an increasing demand for quantified expertise.

\footnotetext{
${ }^{7}$ In employment discrimination cases, the trier of fact is the court, there is no jury. A regular witness is not allowed to give her opinion, only statements on facts.

${ }^{8}$ Notes in the Harvard Law Review are generally written by students and published anonymously. The 1975 note was authored by Tom Campbell (Ph.D. in Economics, Chicago, 1980; J.D. Harvard, 1976), an important contributor to law and economics, especially to antitrust.

${ }^{9}$ The court in Castaneda v. Partida (430 U.S. 482) recognized the role of statistical inference. In Hazelwood School District v. United States (433 U.S. 299), the court endorsed in a footnote the necessity to use a conventional standard to test statistical significance. In Teamsters v. United States (431 U.S. 324), the court enacted that there is no requirement that a workforce mirror the general population in terms of proportion of demographic groups (Teamsters, p. 339 note 20).
} 
I thus argue that economists entered the courtrooms due to changes in the legal setting. Yet, to understand how economists responded to these new demands, the changing institutional and intellectual academic landscape needs to be brought into the picture. The 1970s was a period in which economists had grown comfortable with their identity as purvoyers of rigorous quantitative evidence, for which they were rewarded (Fourcade et al. 2015, Foucarde 2018). It is no coincidence that at the same time, the whole discipline of economics was entering the "applied age" (Cherrier \& Backhouse 2017a). Just as the rise of professional culture affected the whole American society in the postwar period, the professionalization of economics was paralleled with major changes in the corpus, methods and standing of the discipline, especially relating to practices outside academia. However, I will show that economists did not enter the courtrooms with a homogeneous "economist's view." Knowledge produced in court was shaped through the interactions of economists within academia, and with judges and lawyersthe growth of the economic analysis of law during the same period can be seen as a symptom of these interactions. ${ }^{10}$

In the 1980s, the "numbers game" intensified and the financial stakes of expert witnessing increased. Media coverage amplified professional discussions regarding what has become a market with lucrative stakes for experts. Methodological discussions became intertwined with ethical issues faced by experts as "hired guns": available for a price, the gun being expertise itself. Mark Twain's aphorism "There are three kind of lies: lies, damned lies, and statistics" eventually get updated into "Lies, damned lies and expert witnesses" (Meier 1986). ${ }^{11}$ Against the narrative of money necessarily corrupting science, this paper explores the way both

\footnotetext{
${ }^{10}$ On the history of the economic analysis of law, see Harnay and Marciano (2009) and Medema (2018).

${ }^{11}$ Another version reads: "Joked a Chicago trial, lawyer at a recent conference, there are three kinds of liars: 'The common liar, the didactic liar, and the scientific expert" (Killingsworth 1991, p.71).
} 
economists and courts discussed how to maintain the objectivity of the judges and the credibility of the experts.

Despite a large literature on the history of law and economics, there are few historical contributions on what happened since the 1970s, on economists' practices in courts and on the field of forensic economics, except for reminiscences and reflexive pieces by practitioners. ${ }^{12} \mathrm{I}$ thus analyze the courts' and economists' discourses on MRA with two types of sources. First, published court decisions are used as a proxy for reception of MRA by courts. The proxy is imperfect for several reasons. First, many disputes did not lead to a trial and pre-trial settlements are usually not public. Second, all trials do not translate into a published decision. Third, decisions varied considerably in their recording of the experts' testimony. ${ }^{13}$ This paper is based on the analysis of 26 cases occurring between 1971 and $1989 .{ }^{14}$ The economists' discourses are also inferred from a second type of sources: articles published in academic journalsessentially law, law and economics, economics and statistics journals. These discourses are embedded within three different contexts: the US litigation history, academic debates on wage differentials, and the institutional settings of expertise within the courts.

The three periods I identified are the early encounters of economists and judges in employment litigation from 1971 until 1980. One specific case (Vuyanich) is analyzed as a turning point towards a second period characterized by the consolidation of the use of MRA in courts, as showed in published decisions (1980-1986). Starting in the mid-1980s, the last period is defined by the institutionalization of expert witnessing (1986-1989).

\footnotetext{
${ }^{12}$ For a general history of law \& economics since the 1970 s, see Cohen \& Wright (2011) and Mercuro \& Medema (2006).

${ }^{13}$ I use trial transcripts whenever quoted in the decision or secondary literature. Courts' 'dockets' (transcript) are not available in electronic form before 1988 and could only be accessed from each courts' physical site.

${ }^{14}$ See Appendix 1 for the selection criteria of the case study.
} 
I first show how the early reception of MRA by the courts did not involve systematic rejection but a large amount of skepticism (section 1). I then illustrate how economic theory underlying MRA was progressively introduced in the "judicial tool-kit" via an extensive recording of experts' testimony in decisions and references to economists' publications (section 2.1). I then show how the debates in the courtrooms relate to the debates in academia (section 2.2.). Finally, by 1989 , practical and ethical questions regarding the institutional settings of experts' testimony took center stage: I analyze how these debates reflect the increasing professionalization of the field (section 3).

\section{A TALE OF TWO EPISTEMIC CULTURES, 1971-1980.}

\section{Judging Economics}

In the early 1970s, two decisions established the underlying evidential pathway which most cases followed during the 1970s and 1980s. The 1971 Supreme Court decision in Griggs v. Duke Power \& Co. inaugurated the disparate impact doctrine.

If an employment practice which operates to exclude Negroes [females] cannot be shown to be related to job performance, the practice is prohibited. (Griggs, pp. 430434) $)^{15}$

\footnotetext{
${ }^{15}$ The origins of the doctrine have been associated with the endorsement of personnel administration professionals' definition of best practices (Dobbin 2009, p.222). This narrative converges with the crisis of legal theory, subsequent to the turmoil of 1960s and criticisms of "judicial activism" (Green 2009). Legal scholars would increasingly look towards social sciences to find new interpretative principles in the context of the amplification of "Law \& - " movements such as Law \& economics or Law \& society (Mercuro \& Medema 2006, p.19).
} 
The case targeted the use of aptitude tests which have a disparate impact on protected groups without being related to job performance. In McDonell Douglas Corp. v. Green (1973), the doctrine of disparate impact crystallized in a three-steps procedure. First, the plaintiff was required to establish a prima facie case of discrimination. This generally implied showing a clear disparity of a certain outcome (e.g. wage, promotion rates) between the majority and the protected group. Second, if the plaintiff was successful, the burden of proof shifted to defendant who had to articulate non-discriminatory reasons for the observed disparities. Finally, if the defendant's rebuttal was successful, the plaintiff had to show the defendant's narrative was a “pretext". In disparate impact cases, evidence of intention was not required, which considerably lowered one of the major evidentiary difficulties.

By the mid-1970s, MRA was being used at every stage of this process to prove or disprove quantitatively a pattern of systematic discrimination. Courts had to assess the admissibility of the method itself, the probativeness of evidence as well as the credibility of the expert. The evolution of litigation theory towards disparate impact led courts to judge what became identified as a landmark of labor economics.

MRA was used in few cases in the early 1970s (Fienberg 1972) and was usually not even mentioned in the decision. This changed in the mid-1970s. I use two cases to illustrate how reception of MRA can be first casted as the meeting of two epistemic cultures. ${ }^{16}$

In the 1970s, the Stockham Company was a major industrial employer of Birmingham, Alabama, producing valves, iron pipes and fittings. In 1966, three employees filed a suit alleging for racial discrimination with the Equal Employment Opportunity Commission (EEOC). They asked for back pay, the end of segregated facilities and a ban on discriminatory

\footnotetext{
${ }^{16}$ In the work of Knorr Cetina (1999), epistemic cultures refer to practice of sciences that includes ways of knowing, reasoning, producing evidence as well as publication practices and other institutional aspects. While I wish to place the present work in the same tradition I do not use an anthropological method, but rather an approach centered on written sources closer to Camic, Gross and Lamont (2011)'s perspective on practices.
} 
hiring and promotion practices. Two weeks before trial, a conciliation agreement between the EEOC and the company recorded the end of segregated facilities. The district court ruled in favor of the defendant in March 1975, and two years later the three employees appealed the decision. In 1982, a court settlement superseded the 1975 ruling: \$1.65 million was transferred as back pay to 5,600 African American employees.

At the time of the second trial in 1975, the economists James Gwartney and Joan Gustafson Haworth served as the defendant's experts. ${ }^{17}$ They offered evidence that differences in earnings and job assignments reflected non-discriminatory factors. Nine "productivity variables" were included in a classical MRA: years of schooling, achievement, seniority, skill level, outside craft experience, outside operative experience, absenteeism, and merit ratings (James, pp.332333). The Court considered the method relevant to the case but rejected the inclusion of some variables as "tainted". "Skill level" was determined from the employees' job classes: he was skilled if he worked in a skilled job class. The distribution of the work force in the various job classes was part of the alleged discriminatory practices. The court found that "[a] regression analysis defining 'skill level' in that way thus may confirm existence of employment discrimination practices that result in higher earnings for whites" (James, p.332). Similarly, the "merit rating" variable was deemed subjective and unreliable. Ratings were made by the foremen and department supervisors without any explicit standard or written guidelines, entirely to the discretion of the (white) supervisors, whose decisions were not subject to evaluation. Gwartney recognized this second variable may be tainted in the transcript, conceding he made no attempt "to control or check for racial bias" (James, p.332, n.31).

\footnotetext{
17 James Gwartney wrote his Ph.D. on the measurement of discrimination (University of Washington) under the supervision of Douglas North. He spent his academic career at Florida State University department of economics. Gwartney is one of the promotors of the World Freedom Index, that originates from a 1984 Mont Pèlerin Society meeting (Lawson 2014). Joan Gustafson Haworth (1932-2012, Ph.D. in Economics, University of Oregon 1968) held a professorship in economics at the same department. She mainly taught econometrics. She was a consultant to the U.S. Commission on Civil Rights (1975-1976) and worked for several government agencies. In 1980, she created one of the first consulting firms providing economic expertise for legal disputes (CSWEP 1992).
} 
Gwartney's inclusion of "education" using years of formal education as a productivity variable was also criticized by the Court. Applying the Griggs doctrine, the Court judged this variable was wrongly used as "education [wa]s not a job requirement at Stockham" (James, p.332).

In 1976, or roughly a year later, James Gwartney was again called upon to testify, this time in the aforementioned Stasny case. Stasny involved a class action claim for gender discrimination in pay and promotion at Southern Bell Telephone \& Telegraph in Charlotte, North Carolina. A subsidiary company of AT\&T, Southern Bell has already been through of a landmark gender discrimination case in the late 1960s. ${ }^{18}$ Occupations were segregated according to sex, with women occupying the lower paying jobs. Contrary to prior lawsuits where only descriptive statistics were provided, both plaintiff Stasny and Southern Bell produced MRA to support their claims. The defendant used Gwartney's results to claim that statistical disparities were either statistically insignificant or resulted from non-discriminatory factors such as levels of education. The court questioned the usefulness of the regression analysis because of errors in the datasets as well as its use of "intellectually questionable" assumptions (Stasny, p.323). First, Gwartney excluded from his database the persons "who accepted relief under the 1973 and 1974 Consent Decrees" (Stasny, p.323, n. 2). ${ }^{19}$ According to the court, this choice "does create the danger $[\ldots]$ that women who provide the most cognizable examples of sex discrimination may be excluded from defendant's analysis" (Stasny, p.323, n. 2). Second, the Court rejected the use of salary class as a control variable. According to the court, the salary class or job class in general "is not a productivity factor but rather is the result that, theoretically, productivity factors would explain" (Stasny, p.323, n. 3). Job class, quantitatively the most important

\footnotetext{
${ }^{18}$ See Weeks v. Southern Bell T\&T. Co. (408 F. 2d. 228, 1969).

${ }^{19}$ Two consent decrees (agreements that resolves disputes without admission of guilt or liability) between the Bell companies, the EEOC and the Department of Labor were signed in 1973 and 1974. Back pay was accorded to some members of the protected class and quantified objectives of promoting women via an Affirmative Action Job Class system were put in place.
} 
explanatory factor of observed differentials, was deemed "not explanatory at all" (Stasny, p.323, n. 3). The defense was also accused of offering its own definition of appropriate "labor pools" which the expert defined as the groups of employees upon which the company has "historically drawn candidates" (transcript, pp. 828 and 955; Stasny, p.327, n. 5). The estimation procedure itself was also under criticism, as Gwartney was accused of not taking into account multicollinearity between variables (Stasny, p.324). ${ }^{20}$ The court then proceeded to question the objectivity of expert witnesses in general as "the conclusions produced by the regressions appear to depend in large part on the side producing them" (Stasny, p.324). In the end, the judge relied heavily on descriptive statistics provided by the firm and very little on expert's testimony. He pointed to evidence of discrimination in promotion practices, adding that women were also denied access to the annual appraisal conference, concluded that the overall opinion-based appraisal system "provides an ideal environment for disparate treatment of sexes" (Stasny, p.328).

Several lessons can be learned so far from the early reception of MRA in court. First, it is worth noting that despite different historical contexts and socio-economic conditions underlying gender and racial discrimination, the finding of facts mobilized the same tools-litigation doctrine as well as MRA. Second, the method of MRA itself was usually deemed relevant however its practical application to the particular cases was often discussed. The inclusion of each variables was generally discussed in relation to other type of evidence. Third, nonstatistical evidence was central: in the two aforementioned cases, plenty of evidence regarding still pervading discriminatory practices were available to the courts. In the James case for example, oral testimonies established the company's facilities and practices were segregated until the time of the trial-from the toilets, canteens, and locker rooms to extra-work activities

\footnotetext{
${ }^{20}$ Colinearity, a term coined by Ragnar Frisch in the 1930s, and multicollinearity of variables was hardly new to economists in the 1970s.
} 
such as Bible classes, baseball and bowling teams. Fourth, by bringing the tainted variables argument and the exclusion of education as not job-related, the judge targeted the perceived arbitrary evaluation and promotion procedures in both companies, and especially, the absence of guidelines for such procedures. The questioning of the use of some variables by the judges was based on the courts' interpretation of their applicability to the case in question, not on the proper use of a Mincer equation. But the meaning of variables themselves and their articulation in a dynamic model of how employers actually made decisions were also interpreted according to different framework by the judge and the economists. This last point raises a broader question related to the choice of what is given, what is controlled for in an analysis. James Gwartney's testimony was praised in other trials (see e.g. Paxton v. Union National Bank). His credentials were not disputed. It was rather conflicting epistemic choices, as well as value judgments. One of the many ways judgements enters economics is by the "determination of the scope of variables (what is included and taken as given and/or constant and thereby excluded from explanatory status, a process of abstraction involving the setting or reality in a special perspective" (Samuels 1992, p.240). ${ }^{21}$ The hiring process in both cases analyzed in this section was considered as given by Gwartney. The use of standard variables such as education or job classes was based on stylized facts established in economics, as well as beliefs in how a market system works and knowledge on how relations should be derived from and confronted to data. This hiring process was however considered to be explained by the courts. When rejecting the inclusion of specific variables used as control, the court rely mainly on non-statistical evidence. In other cases, with the absence of such contextual elements, the same variables used as control would not have been deemed "tainted. ${ }^{22}$ Just as the economists' choices were contested by judges, judges' choices were also opened to criticisms by economists.

\footnotetext{
${ }^{21}$ On value judgements in economics in general, see Cherrier (2008).

${ }^{22}$ For example, inclusion of job class as variable, when testing for other aspects of discrimination than hiring became standard; e.g. Coser v. Moore in 1983 in which Meier and Welch testified, and Chang v. University of Rhode Island in 1985 in which Siskin testified (see also Fienberg 1989, p.95, for a discussion and other cases).
} 
Teaching Economics to the Judges

It is clear from the Stasny transcript that Judge MacMillan was not familiar with standard econometrics of the time, even if he understood intuitively the collinearity of variables. On some occasions, judges' decisions were very explicit about this lack of understanding. In Kyriazi v. Western Electric Company for example, the court rejected expert testimony by Dr. John Ullman,

in large part because his criteria and their valuation were quite arbitrary and subjective, and, frankly, in larger part because his testimony was simply not comprehensible to the Court. (Kyriazi, p.25)

Economists criticized the courts' inability to deal with economic theory and basic econometrics. They usually focused on lawyers' and judges' lack of credentials: very few were in fact trained in statistics and economics in the 1970s. Yet, some economists produced a mixed discourse based on economics, but also fueled by value judgements regarding the proper sphere of law.

For example, labor economists Ehrenberg and Smith criticized of the use of "labor pools" in the courts. ${ }^{23}$ Labor pools are group of individuals from which workers are hired, usually referred as the qualified workforce. According to Ehrenberg and Smith, courts rather equates labor pools with any individuals, qualified or not (Ehrenberg and Smith 1983, 7, p.10). This statement goes further that stating a lack of understanding of a particular statistical technique. Another strong reaction from economists concerned the way courts rejected the use of education as a variable. Economists advocated the use of variables based on well-established stylized facts

\footnotetext{
${ }^{23}$ Ronald Erhenberg (Ph.D. Northwestern, 1970) and Robert S. Smith (Ph.D. in Economics, Stanford 1971) are the authors of the best-selling textbook Modern Labor Economics: Theory and Public Policy (first edition in 1982, $12^{\text {th }}$ edition until 2015). They also testified in courts.
} 
on the relation between earnings and workers' characteristics such as education. The courts' decisions to disqualify some variables usually used by economists as proxy for productivity were perceived as "disconcerting" (Gustafson Haworth and Haworth 1976, p.50). Courts rejected such variables on the argument they were not "job-related": if diploma was not an (explicit) requirement for a specific job, its inclusion in a MRA was usually rejected. Economists however relied on an established relation that earnings are correlated to level of education. To reject diploma or any variables associated with education to explain the variation in economic outcome was thought as unscientific. Haworth and Gwartney accused the courts to rely on what they framed as the "warm body hypothesis" (Haworth \& Gustafson Haworth 1976, p.49) according to which "all people who have a warm body are equally qualified" (Gwartney et al. 1979, p.643). According to them, the job-relatedness criterion implied that judges considered all individuals equally qualified, regardless of differences in education. For Gwartney et al., this was considered "legally ambiguous, theoretically unsound and economically unreasonable" (Gwartney et al. 1979, p.641). The main theoretical basis to oppose such narrow interpretation of Griggs was its rejection of the "cost conscious employers" hypothesis.

Such view implies that literally millions of employers in this country and other countries have been irrational in rewarding educational achievement. (Gustafson Haworth and Haworth 1976, p.50).

Criticisms of the courts' resistance also raised questions about the proper sphere of law in economic life. Ehrenberg and Smith lamented "courts [were] now allowed to make judgments about the business necessity of a firm's hiring agenda", a step "fraught with serious implications for a market system" (Ehrenberg and Smith 1983, p.14). Title VII of the Civil Rights of 1964, 
Joan and Charles Haworth argued, should not be used to assign the cost of "correcting past discrimination" to a private employer (Haworth \& Haworth 1976, p.49).

Gwartney et al. (1979) exposed at length this "economist's view" in a publication widely acknowledged in courts' decisions. Going back to Adam Smith's "discovery" of the economic forces behind the impact of skill on earnings, the authors insisted that some unquantifiable differences between individuals were not considered by the courts. The main argument was that even if not quantifiable, "the market" was in fact taking into account these differences. Market forces produced strong incentives on employers to establish efficient reward structures. "Imperfect information and uncertainty" did "not change the basic structural relationship between skills and rewards" (Gwartney et al. 1979, p.634). At the very same time however, other economists were questioning this structural relation between skills and rewards. ${ }^{24}$

The early reception of MRA in the courts is better described as the collision of "two cultures" (Fienberg 1989, p.143) rather than using Posner's metaphor of an isomorphism between legal doctrine and economic theory as two disciplines that naturally fit together (Posner 1999, p.91). ${ }^{25}$ Isomorphism does not fit well once you look at the practices of economists and legal community before the 1980s. Going back to Judge MacMillan's confusion of natural log for natural law which opened this paper, it should be added that the confusion was followed by the expression of a clear epistemic rift with the expert witness. After explaining the various "weights" of different factors were "determined by the computer program", the judge asked the expert

\footnotetext{
${ }^{24}$ Gwartney et al's implicitly target the application of signaling theory to labor market (Spence 1973). This broad label includes filter theory of hiring procedures (Arrow 1973) and statistical discrimination (Arrow 1972, Phelps 1972), as well as the literature on principal/agent models applied to labor economics.

${ }^{25}$ On the differences of epistemic cultures, see the concise comparison of the two regimes of enunciation (in science and in law) in Bruno Latour's ethnography of administrative French law making (2010, p.235).
} 
[h] ow does this theory cope with the absolutely arbitrary decision that an employer might make to pay one person $\$ 5$ and another $\$ 10 /$ hour for doing the same work? (Trial transcript as quoted by Fienberg 1989, p.152)

The judge was in fact challenging the applicability of a method based on the "law of large numbers" to a specific case. This exchange illustrates very well the different way judges and economists establish causality, what Brandmayr refers to (in another context) as the difference between "“the statistical probability' of a scientific law" v. "the high 'logical probability' that the law applies to an individual case" (Brandmayr 2017, p.367-368). The judge seems to have in mind a different behavioral hypothesis than the economist concerning the motivation of employer's decision and the way to prove causality, hence, responsibility. The whole point of a trial was to establish responsibility by looking at justification of employment decisions in a specific case. Motivation, if not observed by proof of intent, has to be scrutinized via justification of employers, procedures, or more to the point, the absence of such procedures. Judges did not reject MRA results only because they did not understand them, a narrative put forward by many economists early on, but instead rejected some model specifications used as matters of law and because they share a different epistemic culture. Judges challenged behavioral hypotheses as well as economic theory in its capacity to provide local evidence, i.e. relevant measurement of discrimination regarding specific cases. Beyond the old epistemological issues of inference and generalization, the early reception of MRA in court underscores the many difficulties to transfer knowledge from a sphere to another, while using the same concept of "discrimination". Judges taught economists their vision of the employment relations and economists judged the way the law was implemented, both sides producing a mixed discourse, based on their specific knowledge and value judgements regarding the proper sphere of law. After early encounters in the 1970s, judges and economists moved toward less 
polarized positions than that of Judge MacMillan in Stasny or as expressed by economists in Gwartney et al. (1979).

\section{WITNESSING FOR ECONOMICS, 1980-1986.}

\section{Endorsing "The Human Capital Theory”}

The unusual but widely read decision in Vuyanich v. Republic National Bank (1980) is worth quoting at length, not because it is a representative case, but because it is a significant one. ${ }^{26}$ The very long opinion by Judge Higginbotham is almost entirely based on the examination of "adjusted statistical evidence" (Vuyanich, pp. 251-386, 80 pages out of 127) with a lengthy section devoted to "the theory behind the parties' mathematical modelling" (Vuyanich, pp.261279).

In 1969, plaintiff Joan Rance Vuyanich, an African American woman, was asked to resign after several months of employment at the Republic National Bank, Dallas (Texas), due to a "clash of personalities" with white coworkers. When she asked instead for a transfer, her supervisor replied that she "probably did not need a job anymore since her husband was white" (Vuyanich, p.231). ${ }^{27}$ She was later discharged. Employment decisions at the Bank, the largest in the South, had already been met with several charges of discrimination. ${ }^{28}$ At the trial, top executives

\footnotetext{
${ }^{26}$ Fienberg recalled the decision was "widely read, not only by lawyers, but also by statistical experts who were preparing material for trial. [...] Many parties who had retained a single expert hurried to hire additional experts, especially economists." (1989, p.25)

${ }^{27}$ Note the Supreme Court declared unconstitutional the last States' laws that forbid inter-racial marriages only in 1967 (Loving v. Virginia). The decision applied to Texas and 15 other States in the U.S. South.

${ }^{28}$ Between 1968 and 1973, five charges were filed with the EEOC, "as part of a total of 43 charges for the 10-year period of this suit" (Vuyanich, p.247). The EEOC itself accused the Bank in 1974, and a conciliation agreement was signed in 1976, contested and amended the next year.
} 
described a "spiritual change" in the early 1970s, implicitly admitting previous systemic discrimination (Vuyanich, p.260). An affirmative action plan was implemented in 1971 with the main result of producing a monthly status report on the percentages of hires that were minorities (women included). A lack of qualified workforce in the protected classes, namely women and African Americans, became the main line of defense of the Bank. After a complex procedural history, a consolidated Vuyanich case was certified as class action: claims for "across-the-board" race and sex discrimination were finally brought to a district court in 1978. The five-week proceedings focused on the MRA results produced by labor economists Francine Blau and Janice Madden, testifying for the plaintiff, and Judith Stoikov, for the defendant. ${ }^{29}$

The decision first displays a discussion of the data, then of the theory and estimation techniques, before applying law to the results of the MRA.

The section on data sources discussed at length the choices made by the parties. As a result of organizational changes, the Bank computerized its "personnel jacket" (register of employees) in 1973 and applied a new system of job evaluation known as the "Hay system". ${ }^{30}$ This made for an "unusually rich source of data" and a "really large impressive sample" for a lawsuit, according to the court (Vuyanich, p.255). The parties used the same tapes, but the plaintiff's

\footnotetext{
${ }^{29}$ Madden and Blau were full-time academics while defendant's expert, a former Associate Professor in Economics, was at the time a Senior Consultant with National Economic Research Associates, one of the oldest economics consulting firm. Madden (Ph.D. in Economics, Duke University 1972) developed theories of sex discrimination in the context of imperfect competition (Madden 1973) and work as consultant, especially for the Equal Employment Opportunity Commission, between 1979 and 1991. Blau (Ph.D. in Economics, Harvard 1975), a founding member of the American Economic Association's Committee on the Status of Women in the Economics Profession, is a recognized labor economist. She wrote extensively on gender discrimination starting in the 1970s (Blau 1977; 1984). The fact that all experts were women is not surprising: in gender discrimination cases defendants usually ensured that at least one woman was on the team of experts as a strategic move. Expertise work, as consultant or government economists, was also a major alternative to academic careers, especially for women, starting in the 1940s. Many women economists are in fact pioneers in forensic economics.

${ }^{30}$ The Hay Guide Chart-Profile is a method of job evaluation created by the management consulting firm Hay and Associates. "Hay Points" reflects specific competences and are used to calculate the relative worth of jobs. It was used by firms to ensure comparable jobs receive equal pay. See also note 32.
} 
expert merged information in a different way to facilitate the use of a specific software. ${ }^{31}$ Then, the decision went on to enumerate what variables and functional form should be adopted, which estimation techniques, robustness checks, level of coefficient of determination were most common to the type of MRA used in the case, and finally asked the experts witnesses "what can go wrong?" (pp.273-275). Describing at length the specification errors, the problem of overinclusion of variables and the subsequent issue of collinearity to considerations on heteroscedasticity, the decision then described the differences between the plaintiff's and defendant's models. The plaintiff' experts found statistically significant disparities between men and women. However, Madden and Blau used "Hay points", rather than job categories, to control for "comparable job". The court therefore rejected the evidence of discrimination as a matter of law. Indeed, the Equal Pay Act of 1963 specified only unequal pay for equal worki.e. only the same job category was considered by the law, not "comparable" job category. This restriction did not apply to race discrimination under Title VII of the 1964 Civil Rights Act. Hence, the huge disparities found by Maddden's and Blau's model between African American and whites were "fully supported by the human capital theory", and deemed sufficient to establish a prima facie case for racial discrimination. The defendant's rebuttal was rejected as “mere 'stereotyped' impressions” (Vuyanich, p.304).

Vuyanich was the first case to produce a substantive exposition of the theoretical bases of MRA. The court justified this long détour as a mean "to ensure that any hidden value choices are not introduced by the quantitative techniques" (Vuyanich, p.261). The novel aspect of the decision

\footnotetext{
31 The court's decision also unusually described the use of the software: the Statistical Package for the Social Sciences, a group of standardized statistical computer programs developed for mainframe computers, and later for personal computers. Created in 1968 by three students at the University of Stanford, SPSS was incorporated in 1975, following the same model as many software, from university projects to private companies. One of the programmers of SPSS testified at the trial. For a history of the impact of computerization on the development of economics since the 1970s, see Renfro (2004) and Backhouse and Cherrier (2017b).
} 
relied on the impressive list of economic literature quoted as secondary authority. ${ }^{32}$ It first included citations of economists' papers published in law journals (Gwartney et al. 1979, Fisher 1980). Second, the opinion delivered a detailed description of "major findings" of the "widely accepted" human capital theory, quoting seminal contributions (Becker 1971, 1964; Mincer 1974), as well as relatively recent empirical studies published in economics journals (Blinder 1973; Oaxaca 1973; Gustafson Haworth, Gwartney and Haworth 1975), and a survey-article by historian of economics Mark Blaug (1976). The decision also referred to general economics textbook literature (Samuelson 1980) and to a series of (advanced) econometrics handbooks (Kmenta 1971; Johnston 1972; Maddala 1977; Wonnacott and Wonnacott 1979; Pyndick and Rubienfled 1979)..$^{33}$

The decision deemed MRA "an important addition to the judicial toolkit" (Vuyanich, p.267), despite the court's being "uncomfortable" with the "implications" of this "surrealistic cast" (Vuyanich, p.394). The Judge admitted "realizing" "that the esoterics of econometrics and statistics which both parties have required this court to judge have a centripetal dynamic of their own"-namely

They push from the outside roles of tools for "judicial" decisions toward the core of decision making itself. (Vuyanich, p.394)

As a good deal of anecdotal evidence suggests, beginning in the 1980s, time-consuming testimonies based on quantitative analysis took center stage in employment discrimination

\footnotetext{
${ }^{32}$ Secondary authority refers to "authority that explains the law but does not itself establish it" and encompasses sources "such as a treatise, annotation, or law-review article" (Steenken \& Brooks 2015, p.28). Quoted in legal opinions, secondary authority is only persuasive, by contrast with the mandatory or binding status of primary authority (i.e. the Constitution, statutes and regulations).

${ }^{33}$ In reaction to the reception of his surprisingly detailed opinion, Judge Higginbotham "subsequently revealed that he and his clerks took a full month off their other duties to devote themselves to understanding the evidence presented by the experts and arguing about the findings to be reported" (Fienberg 1989, p.21).
} 
cases, at the expense of other type of testimony or evidence (see Fisher 1988; and testimonies of experts in Fienberg 1989). The Vuyanich decision exemplifies the entering of economics within published decisions.

The judicial endorsement of economic tools stemming from human capital theory also had a dynamic of its own: it assembled under the "human capital theory" label various strands of applied microeconomics. The courts, in fact, endorsed a set of tools, rather than one specific version of the "human capital theory", allowing experts to produce different results with the same method or diverging interpretations of the same results.

\section{Diverging Interpretations of the Smoking Gun}

The rise of economics language within legal decisions has to be compared to the findings of the economics literature at the time. The absence of qualified applicants was the main line of defense for many of the companies accused of discrimination. It was also one of the main empirical results of many studies on minorities and on women in economics: groups' human capital endowments differed on average. At the turn of the 1970s, contrasting interpretations of these "average differences" between groups led to diverging empirical strategies deriving from alternative theoretical hypotheses. If human capital endowments were thought of as voluntary labor supply decisions, enquiries turned to study the impact of other differences (from quality of schooling to IQ differences) or to measure the impact of larger trends such as the effect of migration from the U.S. South. A second research perspective was to study the determinants of decisions to invest in human capital, not only on the supply side (private returns to education) but also on the demand side. Employers' decisions were then modelled as decisions under uncertainty in a principal/agent asymmetric setting (Lundberg and Startz 1983). 
Analyses looked at employers' use of education level or gender as a proxy for unobserved characteristics (screening or filter theory and statistical discrimination). These two theoretical orientations were both compatible with observed differentials, but the second approach, especially the filter theory, do not assume diploma measures "acquired skills" (Arrow 1973, p.194). A third (much more diverse) orientation developed out of criticisms of the "neoclassical" modelling of the labor market and included segmentation theories as well as feminist and radical perspectives. ${ }^{34}$

A first major debate in academic literature, concerns occupational segregation. Perspectives that insist on segmentation and segregation usually underscore structural aspects of inequalities much broader than approaches centered on the measurement of discrimination. Many economists in that perspective produce analytical work on the comparable worth question. While out of the scope of this paper, the role of economists in the comparable worth movement in the 1970 s bears some strong connections to the way courts narrowly interpreted "equal work". ${ }^{35}$ This debate was central to the definition of the non-discriminatory wage structure economists should consider to measure discriminations, and give rise to analyses of nepotism (e.g. Goldberg 1982).

\footnotetext{
${ }^{34}$ On the history of feminist perspective see Figart and Mutari (2005). For radical criticisms of "neoclassical" theories of the labor market, see Bergmann (1986), Marshall (1974), and Cain (1976).

${ }^{35}$ Comparable worth is defined by "the application of a single, bias-free point factor job evaluation system within a given establishment, across job families, both to rank-order jobs and to set salaries" (Remick 1984, p.99). Bergmann, Blau, Madden has been contributors to this literature, see Madden (1987) for a review of major economists' contributions. A good summary can be found in Bergmann (1989). This literature paralleled and infused the wage realignment demand that emerged from women's movement. Controversy generally concerns which jobs are comparable and how to measure comparability. In Vuyanich for example, the Judge interpret "equal work" in a strict sense, not "comparable work". As the Equal Pay Act of 1963 was seen as restrictive, especially because based on a strict definition of "equal work", many gender discrimination claims were filed under Title VII of the Civil Rights Act instead. In the 1980s, battles in courts for application of the comparable work principle were largely loose, while collective bargaining, state legislature-notably in the state of Washington and Minnesota-resulted in some successes. In the only Supreme Court decision to mention comparable worth, County of Washington v. Gunther (1981), the court declined to address the issue: while enlarging the notion of "equal work", it did not endorse the principle. For a general history, see Turk (2016, Chapter 4) and ChassonneryZaïgouche (2019).
} 
A second central debate questions the respective effects of legislation and competition on labor force composition and wage differentials. ${ }^{36}$ It also comprises implicit view of merit and how to measure it. While most economists agreed on the basics of wage decomposition methods, there was no consensus on the interpretation of the "other residual", nor on how to measure the “smoking gun". ${ }^{37}$ In 1986, Blau and Ferber, reviewed the empirical literature available on wage decomposition methods and outlined the same three orientations found in research on human capital from the 1970 s and $1980 \mathrm{~s}^{38}$

First, unexplained differences may reflect the incompleteness of the models, specifically, if omitted variables are correlated with average differences between groups, discrimination may be overestimated with such a method. Second, some variables may reflect the indirect effect of discrimination (e.g. pre-labor market discrimination) or the feed-back effect of expected discrimination on choice of human capital investment, hence the method would, in this case, underestimate discrimination. A third perspective moved the focus to occupational segregation, where the choice of occupation itself may reflect the adverse effects of discrimination. Of course, multiple factors could be at work here, as Blau and Ferber noted, which further complicated the analysis:

In the not implausible case that both discrimination and choice play a role, neither procedure will be unbiased. (Blau \& Ferber 1987, p.317)

\footnotetext{
${ }^{36}$ See the debates in the AER opposing Gwartney and Ashenfelter, among others, in the first half of the 1970s. Central reference in this debate is Donohue and Heckman (1991) who found a positive effect of 1960s antidiscrimination legislations on minority's economic outcomes.

${ }^{37}$ The "other residual" is a reference to growth models and their link to human capital (Holden and Biddle 2017). The "smoking gun" metaphor was used by many economists to oppose the indirect aspect of the Oaxaca-Blinder method, especially those who advocated for more direct measurements of discrimination using field and lab experiments (Riach and Rich 1991): while chasing the smocking gun, no information on who pulled the trigger and why was gathered.

${ }^{38}$ Blau and Ferber's paper was presented in the same 1986 ASSA-AEA sessions as Ashenfelter and Oaxaca (1987), which initially concerned international differences in wage gaps, not economists in the courts. The session "The Economics of Discrimination Thirty Years Later" also included a critical assessment of "neoclassical" theories of discrimination by Thomas D'Amico. Discussants were Gary Becker and Isabel V. Sawhill (Ph.D. in Economics, New York University 1968). Sawhill is a pioneer of the use of MRA (Sawhill 1973); her career was mostly spent in government, first in the Department of Labor, and later in the Clinton Administration.
} 
Because of data availability issues and due to the characteristics of the legal context itself, additions to the "judicial tool-kit" from economics were not a perfect mirror of economists" tool-kit of the time and in-the-making. For example, instrumental variables and quasiexperimental methodologies were not introduced in the courts however some experts did use it in academic research or refer to it. Along with the fact that these methods were not widely used yet (see Panhans and Singleton 2018), the constraints regarding the data is an important cause of this. Experts were usually required to work on exhaustive firm datasets (e.g. all the individuals of a firm) while those data were usually incomplete (because of high attrition rates and/or errors). However, randomized samplings methods were seen as a benchmark by experts, especially by statisticians such as Meier or Dempster, who also testified in medical lawsuits (see Dempster's testimony in Commonwealth in 1978).

But the same debates, especially on the interpretation of results, were present in both academia and the courts. ${ }^{39}$ In a 1991 AER paper, labor economist (and frequent expert witness) Mark Killingsworth, blamed both the courts' lack of economics knowledge and the existence of unsettled debates between economists — such as "the widely divergent estimates of female labor supply elasticity that have appeared in the literature" (1991, p.77) —for the disparate impact of expert testimony in court. Experts, he said, should display how and why they chose their models and hypotheses, and quantify the impact of alternative choices on the results (Killingsworth 1991, p.72). This conception of the practices of economists echoes the main result of the social study of sciences in courts: unpacking the social construction of scientific facts.

The prevalent assumption was that scientific truth or consensus was always "out there" for the law to find and that any failure to accomplish this goal was due to

\footnotetext{
39 See especially discussions on sensitivity checks and the need for better research design (see Rubinfeld 1985; Dempster 1988), or on selection biases (Bloom \& Killinsworth 1982).
} 
imperfections in the machinery of the law. [...] The difficulty of locating facts, truth, or consensus now seems to be embedded in the way science works. (Jasanoff 1992, p. 356).

Economists' discourses started to acknowledge this social aspect in the construction of knowledge in court. As we moved through the 1980s, the practice of expert witnesses in discrimination cases was increasingly defined along the lines set out by Franklin Fisher in his oft-quoted 1980 article, "Multiple Regression in Legal Proceedings". This note can be seen as the equivalent to the Vuyanich decision from an economist' point of view. Fisher was a central contributor to antitrust economics, an early contributor to the economic analysis of law (Fisher 1958) and a major participant in litigation as expert witness. ${ }^{40}$ In his short and accessible paper, Fisher's delivered clear contours for the use of MRA in the courts, without quoting much literature, in a rather textbook-style. Rather than endorsing a general theory of the labor market, Fisher insisted that MRA was a "device" very well suited for use in employment discrimination cases. The MRA's growing importance in the courts fits neatly into the historical narrative of the so-called "human capital revolution" as a dispersion of tools, not as a theoretical revolution. But there was no unique way of using these tools.

After Vuyanich, the use of MRA became more visible in published decisions. Decisions in the early 1980 s clearly endorsed some principles related to the application of MRA including some relative consensus on the type of variables to be included, on alternative modelling strategies and estimation procedures, and on the need to produce specific (and not theoretical) criticisms as acceptable rebuttal. The Supreme Court decision in Bazemore v. Friday (478 U.S. 385) in

\footnotetext{
${ }^{40}$ Fisher (Ph.D. Harvard, 1960) was an influential MIT faculty member, especially as a supervisor (Svorenčík 2014, Duarte 2014), and as a teacher of econometrics (Cherrier 2014, 27-28, 35-36). He testified in more than 40 antitrust cases, including the famous IBM case, dismissed in 1982.
} 
1986 illustrated these developments. It constitutes the more extensive treatment of MRA by this court. In this case, more than fifty employees had sued the North Carolina Agricultural Extension Services (NCAES) — whose mission was to provide "useful and practical information on agriculture and home economics"-for wage discrimination according to race. The Justice Department introduced regression analysis, showing statistically significant racial disparities for data regarding the year 1971 and 1974. The district and appeal courts ruled in favor of NCAES, rejecting the regression's result because Charles Mann, the government expert, failed to account for all the relevant variables, such as "across-the-board and percentage pay increase" (p.399). In a nutshell, the Supreme Court affirmed the broad consensus on the use of the method and stated that all measurable variables need not be included in a MRA, that accounting for major factors was enough; hence ruling against the two previous decisions. This decision was perceived by Ashenfelter \& Oaxaca (1987, p.324) as “equivalent to applying the economists' definition of market discrimination to the factual findings of the case". It also provided latitude for theoretical interpretation of both the functional form and the specification of the models. Although acceptance of MRA in court implied a rise of the "economists" view", it also implied that debates among economists also emerged in the courts. But if two experts tell different stories, based on the same tools, how then can the court decide?

\section{CONTROLLING “HIRED GUNS”, 1986-1989.}

Together with the rise of economists as expert witnesses and the introduction of economics literature in published decisions, the 1971-1989 period saw economists gaining "jurisdiction" (Abbott 1988) in the Courts. ${ }^{41}$ Economists, but more broadly, some of their tools, became attached to the type of expertise required in employment discrimination case. The increasing

\footnotetext{
${ }^{41}$ As an alternative framework, Stryker, Docka-Filipek \& Wald (2012) interpret the rise of industrial psychologists in court in terms of the social authority of science.
} 
use of economists as expert witnesses brought with it many of the trappings of professionalization, among which was the issue of scientific standards. Concerns over the use of "hired gun" expert witnesses led academic (and consultant) economists to broaden their efforts to shape how courts were using, interpreting, and judging economics. Economists not only began to lecture judges and courts in law and economics journals as already described in section 1, but they also urged "good" academics to step-in and save the courts from "bad" expert witnesses. What emerged, in short, was an exercise in economics quality control, what sociologists of science call "boundary work"- -which simply means the drawing of boundary in terms of shared scientific practices that defines the field as a community of interests and exclude the frauds (Gieryn 1983). It first involved methodological and deontological discussions about how experts can maintain their objectivity and, then, the creation of institutions such as journals and professional organizations aiming at building the credibility of the practice itself. However objective and credible an expert can be, the general impact of expertise also crucially depends on external elements to this expertise.

\section{Maintaining Objectivity}

In Penk v. Oregon State Board of Higher Education (1985), a dream-team of expert witnesses, all of them major actors of the early use of MRA in court, testified for the defendant in a sex discrimination lawsuit brought by 22 women faculty members. Bernard Siskin, at the time a senior research statistician in a consulting firm, led a team of "nationally recognized" (Penk, p.15) experts including Joan Gustafson Haworth, Finis Welch, and Paul Meier. ${ }^{42}$ The decision

\footnotetext{
${ }^{42}$ Finis Welch (Ph.D. Economics, Chicago, 1966) is a well-prized labor economist working on the impact of education on earnings-while at Chicago, he worked with Gregg Lewis and Theodore Schultz. He is also the cofounder of Stata, one of the main statistical software used by economists worldwide. Paul Meier (1924-2011, $\mathrm{Ph}$. D. Statistics, Princeton, 1952) is a bio-statistician known for having fostered the use of randomization in
} 
started with the "search of credibility". The list of the experts' consulting firms, previous testimonies, party's side in previous trials, and outcomes of each cases were recorded along with their academic positions and publication logs (Penk, p.14-15). Beyond academic records, the objectivity of experts was searched in practices of expertise. The plaintiffs' experts-Mary Gray, Barbara Bergmann and Fred Ramsey—-had testified only for the plaintiffs in previous employment discrimination cases, and, of the three, only Bergmann was considered a specialist in labor issues (Penk, p.15). ${ }^{43}$ The court also included Gray's activities in teachers' unions and women's organizations as relevant information in ascertaining credibility. In comparing these teams of experts, the court endorsed the defendant's experts based largely upon perceived "objectivity": defendant's experts had testified for both defendant and plaintiffs in the past, including against each other. Moreover, the court found,

as nationally recognized experts, $[\ldots]$ they have personal and economic, as well as legal and ethical reasons not to "stretch" statistical or economic theory [...]. Although plaintiffs brought out the size of the fees paid to the Board's experts, in order for these experts to continue to generate such fees, they must maintain their credibility. (Penk, p.15) ${ }^{44}$

By contrast, the court found Gray and Bergmann to be biased as they "often appeared openly partisan and argumentative in their responses to the Board's question." (Penk, p.16-17).

\footnotetext{
medical clinical trials, and for the joint survival rate estimator named "Kaplan-Meier". Both Welch and Meier testified in numerous cases and congressional hearings starting in the early 1970s.

${ }^{43}$ Ramsey was a statistician from Oregon State University, not a specialist of labor issues. Bergmann (1927-2015, Ph.D. in economics, Harvard, 1959) was a labor economist, known for having pioneering the use of microsimulation, as well as for her feminist views. A senior staff member of the Council of Economic Adviser during the Kennedy Administration, she spent her subsequent academic career at the University of Maryland. Mary Gray (Ph.D. mathematics, Kansas; J.D. Washington College of Law) is a mathematician, a founding member and first president of the Association for Women in Mathematics. Bergmann and Gray knew each other from their participation to feminist circles and to the American Association of University Professors.

${ }^{44}$ Posner emphasizes this incentive based on the fact some experts were "regular players" (1999, pp.93-94). But it can also work the other way round as a one-time expert has nothing to lose.
} 
In the finding of facts that followed, the results of Gray and Bergmann's MRA were dismembered. The court expressed a general skepticism over "the siren like attraction of mathematical precision", quoting Meier et al. (1984), using arguments from specialists of the method to undermine its probativeness in this case. Criticisms were usually based on a mixed strategy: from merely pointing errors and limits of the method, to displaying alternative interpretations, or suggesting many other causal factors or, sometimes, rejection en bloc. ${ }^{45}$ In this case, the rejection gave the impression that what mattered were elements beyond the method itself, from the politics of the judge to the political commitments of the experts. For example, it is clear from the decision that the fact Gray and Bergmann standing in the public sphere as outspoken feminists played an important role in undermining their objectivity. ${ }^{46}$

Institutionalization of expertise also played an important role in the reception of MRA. Influenced by the evolution of legal rules of evidence in the courts, the professionalization of forensic economics was also linked to its marketization. In a reflexive piece, Fisher warned it was "not easy to avoid becoming a "hired gun" caught in the "game" (1986, p.285). In stark contrast with other literatures by expert witnesses-notably by sociologists and psychologists - the economists' discussions of the rules of the game were loudly silent on the human stakes (it involves the lives of human being), personal emotions and the type of moral responsibility implied. ${ }^{47}$ When questioning the psychological aspect of expert testimony, economists were more inclined to discuss the "bias and heuristics" affecting judges (see Fienberg 1989, p.149-154). The way economists collectively framed the dangers of expert witnesses illustrates how the profession project itself in the public sphere as rigorous provider

\footnotetext{
${ }^{45}$ It echoes Colins' concept of "experimenter' regress" in the public scrutiny of science: there always are scientific alternatives approaches. See Jasanoff (1992, p. 349).

${ }^{46}$ See Jasanoff (2011: 323-330) on the multiple factors that conditions the "performance of objectivity" in courts.

${ }^{47}$ For an analysis of the psychological impact of initiating and living a discrimination lawsuit for plaintiffs, see Berrey et al. (2017, part 2).
} 
of quantitative evidence (Fourcade et al. 2015) but also as dispassionate empiricists. This selfidentification did not prevent economists to develop an important literature at the crossroads of methodological and deontological questions.

In the mid-1980s, the discussion turned to possible reforms of both legal procedures and experts' practices. An example is Daniel Rubinfeld's 1985 paper on "Econometrics in the Courtroom". ${ }^{48}$ While he recognized that the "economists' standard practice" was to find a modelling strategy that "best fits," he urged those working in litigation to report the results from the "searching among alternative models" (Rubinfeld 1985, p.1095). Along with proper reporting, Rubinfeld argued that the dataset should be agreed upon before trial, and advocated the appointment of "neutral" experts on the model of private arbitration-with each parties proposing a set of possible experts and settling on one. ${ }^{49}$

Another challenge was communication. It was necessary to go beyond the mere display of “econometrics [as] black magic" (Fisher 1986, p.277, p.285). Fisher listed practical advice ranging from the need to allocate enough time to explain probability theory to the use of rhetorical examples. Fisher also urged experts to "protect [their] subjective honesty" by hiring research assistants to do the data management (Fisher 1986, p.281).

Debates went further to express the necessity of ethical guidelines. Drawing on examples from other professions — such as psychiatrists regularly pictured as "a clan of hired gun, available for a price to whichever side first knocks on the door" (Meier 1986, p.269)-Meier warned against various "corrupting influences" affecting experts' objectivity, enumerating sins including "bribery", "flattery", and "gladiatorial role", and the need to implement code of professional

\footnotetext{
${ }^{48}$ Rubinfeld (Ph.D. economics, M.I.T. 1972), a student of Fisher, became professor of economics and professor of law in 1982 (UC Berkeley). He is a specialist of law and economics, and coauthored two successful textbooks, on econometrics (Pindyck and Rubinfeld 1976) and microeconomics (Pindyck and Rubinfeld 1989, $9^{\text {th }}$ edition in 2017).

${ }^{49}$ On private arbitration models, see Ashenfelter \& Bloom (1984) and Posner (1999).
} 
ethics. Beyond individual ethics, collective organization led to the institutionalization of an entire new field within economics.

\section{Organizing Credibility}

Calls for standardization and guidelines, driven by both the legal and economists' communities, increased through the second half of the $1980 \mathrm{~s} .{ }^{50}$ The central objective was to foster credibility of expertise as a collective practice. ${ }^{51}$ One example is the establishment of the National Science Foundation's "Panel on the evolving role of statistical assessments as evidence in the courts" whose work from 1984 to 1986 led to the publication of a report in $1989 .{ }^{52}$ Headed by statistician Stephen Fienberg, the panel focused on three litigation areas: damages calculus, employment discrimination and antitrust. ${ }^{53}$ The Panel reviewed an exhaustive list of statistical issues, emphasizing when consensus was reached in academia (e.g., impact of sample size) and when it was not (e.g., the use of reverse regression). The panelists also argued the "blackbox" of method should be opened by the experts when testifying in court as intelligibility and transparency were central issues. A section on the "psychological problems" that this type of expertise induced focused on the epistemic competence of the trier of fact, including references to Kahneman and Tversky's heuristic and biases approach to be applied to judges' lack of understanding of probability theory (Fienberg 1989, p.151).

\footnotetext{
${ }^{50}$ See e.g., the special issue of Statistical Science in 1988 (volume 3, issue 2) on "Employment discrimination and statistical science", half of the 11 articles are written by economists or econometricians.

${ }^{51}$ On the history of credibility (as distinct from validity) in science, see Shapin (1995).

${ }^{52}$ A joint enterprise with the Committee on National Statistics, the Committee on Research on Law Enforcement, the Administration of Justice, members included four statisticians (among them Meier and Finkelstein), one sociologist (Robert O. Lempert), two psychologists and one economist (James Heckman, until 1985). Daniel Rubinfeld served as a consultant for the Panel in 1984.

${ }^{53}$ Fienberg (1942-2016, Ph.D. in statistics, Harvard 1968) has spent his entire career in various departments at Carnegie Mellon. Specialist of legal statistics, he wrote several textbooks on statistics for lawyers. He was part of numerous policy committees regarding the use of statistics in the courts - notably the one who declared the polygraph's results as unreliable in the late 1990s.
} 
On the policy side, the panel went on to give recommendations, some precise and some vague. For example, they called for experts to avoid "mystification" (Fienberg 1989, p.180) and “maintain a degree of professional autonomy" (Fienberg 1989, p.164). No recommendation addressed the controversial issue of contingent fees, but the panel favored adequate funding by federal agencies in "cases in which the absence of such help would constitute a denial of justice" (Fienberg 1989, p.168). The use of "specific devices available to the court for controlling the battle of experts" (Fienberg 1989, p.156) was also encouraged: full disclosure of method and agreement on the data in pre-trial proceedings, more use of Rule 706 of the FRE which allows a court to appoint its own expert, regular publication of critical reviews of expert testimonies, etc.

Two other recommendations addressed the legal and economics professions. To the first community, it was recommended that law schools introduce statistics and social sciences into curricula (p.15, p.181-183). To the latter community, academics and experts were urged to develop guidelines on their own, via professional organizations (p.11, p. 162, p.182). The report seems to have been well received by economists (e.g. Fisher 1990). Many authors insisted that the major problems in expert witnessing were now "institutionally based" and that the "creation and fate of statistical evidence [were] linked and affected by pretrial and trial procedures" (Kaye 1990, p.1273, my emphasis). ${ }^{54}$ Procedures, rather than the scientific content of MRA, were now at the center of focus.

If the recommendations did not translate into immediate reforms, some aspects targeted by the panel were already undergoing concrete changes. For example, economics and statistics were progressively introduced in Law curricula during the same period (Dow 2004). However, in the

\footnotetext{
${ }^{54}$ David H. Kaye is a specialist of forensic science and one of the most quoted "evidence scholar", especially on DNA tests-he did numerous expertise work, among them in the Watergate Special Prosecution Force. In the early 1980s, he wrote extensively on employment discrimination.
} 
1970s, law scholar Henry G. Manne already organized economics training for judges and lawyers (Butler 1999; Teles 2008, p.101-118 and p.207-216). Manne's objective was to help judges understand the "most recent thinking in economic theory" in order to "enable them to better understand the testimony of expert witnesses" (first teachers includes Milton Friedman and Paul Samuelson). ${ }^{55}$ By 1981, the program for Federal Judges had a solid training in econometrics, taught by Orley Ashenfelter. As many as $40 \%$ of sitting federal judges attended “Manne’s flagship program” by 1990 (Butler 1999, p.352). As reported in a Fortune magazine, the program stir a heated debate over the influence of conservative foundations and corporate money over the legal system (Teles 2008, p. 113). ${ }^{56}$ It is no coincidence, but does not count as causality, that the increasingly positive reception of the method by judges happen in the same period of implementation of majors programs in economics education of judges, as well as the first real rise in prestige of law and economics in the legal arena in the 1980s.

Concerning the second recommendation, the most important move toward professionalization came precisely at the time the panel finished its work. The Journal of Forensic Economics (JFE) and the (US) National Association of Forensic Economics (NAFE) were founded in 1987. In his institutional history of the NAFE, Michael Brookshire (2003) traced the origins of the association in small-group discussions happening prior to regional economics meetings and ASSA meetings in the mid-1980s. Organized by John Ward and Jerry Olson with an institutional base at the University of Missouri, Kansas City, a "word-of-mouth" process led to the recruitment of the 153 economists charter members (among them Joan Gustafson Haworth) and the launch of both the journal and the association. ${ }^{57}$

\footnotetext{
55 "19 U.S. Judges Study Economics to Help Them in Work on Bench,” New York Times, 20 December 1976.

${ }^{56}$ See "Judges Discover the World of Economics" by Walter Guzzardi Jr., Fortune, May 21, 1979. According to Ash, Chen and Naidu's (2018) quantitative analysis of the impact of attendance to these training, "participating judges use more economic language, render more conservative verdicts in economic cases, rule against regulatory agencies more often, and render longer criminal sentences" (p.1). On Manne's earlier activities, see Medema (2018).

57 The NAFE counted around 150 members in the early 1990, 800 members in 1997 (Mandel 1997, p.115), around 500 members today.
} 
Two elements, both related to quality standards, help us to understand what was becoming a recurrent issue to the association: the share of academics compared to consultants, and whether NAFE should give certification to its members. First, starting in the early 1990s, "the probability that a new [NAFE] member would be a Ph.D. economist" was diminishing (Brookshire 2003, p.24). The ratio of Ph.D. compared to non-Ph.D. members became framed as an issue of professional credibility for the organization, as less Ph.D. means less credibility. Second, the creation of the NAFE fueled a heated debate on whether the society should have a role in "certification and qualification" of expert witnesses. This discussion first occurred in 1988 (a questionnaire was sent to members), and a committee was appointed in 1991. The association rejected the certification role as too restrictive and complex an issue but released a "Statement of Ethical Principles" members should follow.

The discussions of methods published in the Journal of Forensic Economics echoed the ethical and deontological issues the organization faces, notably the need to organize the market with information such as certification of competence. On the publication side, the information became organized with the inclusion of a JEL code (K 13 for "Tort Law and Product Liability - Forensic Economics") during the 1988-1991 revisions that created the separate field of "Law and Economics" (JEL Code K) ${ }^{58}$ The JEL code validated forensic economics as a subfield of research within the economics discipline. Taken together, these new developments-a professional organization and a specialized journal validated by a JEL code - signaled the institutionalization of an area of research as well as ratify the development of academic consultancy in the domain of forensic economics.

\footnotetext{
${ }^{58}$ See Cherrier (2017, pp. 574-576). Until the 1991 revision, "Economics of Law and Crime" was part of the "Welfare Programs; Consumer Economics; Urban and regional Economics" category.
} 
Consultancy was also established within a specific technical context. One should recall that by the end of the 1950s already, "multiple regression analysis [was becoming] almost a free good in comparison with the previous situation" (Backhouse and Cherrier 2017b, p.107). Bloom and Killingsworth recalled how in the 1970s "[t]imes have changed" because of the "development of powerful computer software $[\ldots]$ now permits analysis of larger data sets at much lower cost and greater speed than was previously possible" (Bloom \& Killingsworth 1982, p.318). Personal computers were introduced in 1981, and the subsequent development of statistical software gave another push to the market of expert witnesses, considerably lowering the barrier to entry of micro-econometric analyses for individual experts and firms.

This market was also increasingly made of academics associated with legal consulting firmsthe vast majority of economists who testified in the 26 cases have been associated with such firms, including Judith Stoikov's National Economic Research Associates, Richard Posner and William Landes' Lexecon, Joan Haworth's Economic Research Services, (Finis) Welch Consulting, or Bernard Siskin's Center for Forensic Economics based in Philadelphia. ${ }^{59}$ Activities of historic consulting firms were focused on the areas of anti-trust, damages calculation, and employment litigation. Discrimination litigation was the third largest source of revenue for forensic economists in 1997 (Thornton and Wald, 1999). With this growth in expected revenue however, came criticism particularly around the neutrality of expertise and ethical questions relative to the experts' fees, a discussion avoided by the 1989 Panel. ${ }^{60}$

\section{Expertise under Pressure}

\footnotetext{
${ }^{59}$ On the "booming market" of expert witnessing, see Mandel (1999, p.113-115).

${ }^{60}$ See the public reception of Linell's Dollars and Scholars (1982). Press article "The Professor as Paid Expert" The New York Times June 12, 1982, by Fox Butterfield. "Putting a Price on Life's Labor Lost; This Computer Knowns What You're worth", The Washington Post, June 18 1983. Public records of fees paid begun with the publication of "Daubert profiles" in the mid-1990s.
} 
The discussion to this point has centered on the supply side of expertise. It gives a lot of importance to economists as experts while the general impact of expertise also crucially depends on external elements to this expertise, from politics to other aspects of the legal system. The 1988 EEOC v. Sears Roebuck case, the last of several cases resulting from investigations by the EEOC task force, is a good example the changing status of expertise in the courts. ${ }^{61} \mathrm{In}$ the Sears case, the two experts involved-Siskin for the plaintiff, Gustafson Haworth for the defendant-produced together 8,275 pages of trial testimony based on the use of MRA. A central feature of the case was the absence of victims' testimony. According to one of the dissenting judges, in this "oversized and confusing case", the EEOC's "failing to produce any flesh and blood victims of discrimination" helped to explain "Sears' lopsided victory" (Sears, p.360). The central dispute concerned whether women were in fact "interested" in commission selling. Siskin, who testified for the EEOC, use four variables "highly correlated" with interest and all related to job experience as a proxy for "interest in the job". This measure was rejected by the Court. ${ }^{62}$ An analysis of the relative merits of the two reports would miss the issue at stake. The absence of flesh and blood victim explain much more the issue of the case than the substantive testimonies of two well-experienced expert witnesses. As do the dramatic changes in the politics of the EEOC.

In 1981 and the subsequent Reagan Administration years, the EEOC policy changed. The initial strategy of supporting huge class actions against symbolic big employers stopped. At the time

\footnotetext{
${ }^{61}$ The special EEOC task force investigated four of the country's largest employers-General Electric, General Motors, Ford and Sears Roebuck - and led to dramatic settlements and acted as an incentive for firms to adopt compliance rules. Stryker also showed how a panel of industrial psychologists, put together by labor economist and EEOC staff Phyllis Wallace, defined the guidelines later used in the Griggs decision (Stryker 2011, p.185188; see also Stryker, Docka-Filipek \& Wald 2012). Wallace was also at the center of the later Bell AT\&T case (Wallace 1976).

${ }^{62}$ At the same trial, historians testified for both sides on whether, historically, women had different interests and preferences than men. See Jellison (1987), Haskell and Levinson (1988), and the response Kessler-Harris (1988). The controversy was related in the New York Times, June 6 1986: "Of History and Politics: Bitter Feminist Debate".
} 
of the Sears case, Reagan had nominated Clarence Thomas to head the EEOC. ${ }^{63}$ Thomas made no secret that this was a case he wanted the EEOC to lose, alienating many EEOC staff members who had worked on it for years. If the final decision was the one of the Court, who ruled in favor of Sears, Thomas more generally terminated the strategic promotion of class-action by the EEOC. One of the major outcomes was that the plaintiffs were "pressured to accept settlement rather than go to trial", as the EEOC was the major "gate" before litigation (Fienberg 1989, p. 140). In this case, the political climate had much more impact on the ultimate resolution than the thousands of pages written by the economists.

By the end of the 1980s, major Supreme Court's decisions led to the rejection of the disparate impact doctrine, essentially because of a reversal in the burden of proof. ${ }^{64}$ It led the Congress to revise Title VII, especially to codify the concept of "job-relatedness" and to provide statutory (and not case law) guidelines for the disparate impact doctrine. The amended Civil Rights Act was signed in $1991 .{ }^{65}$ Describing the changing politics of discrimination and pressure (and reconfiguration of) social movement in the 1980s, as well as major shifts in legal doctrine, are outside the scope of this paper. It should be remembered however that economists' expertise did not operate in the vacuum of specific court cases. Larger social and political forces played a major role in shaping the demand and impact (or absence of impact) of economists' expertise. While economists entered the courtrooms and altered the game, it did not mean their testimonies

\footnotetext{
${ }^{63}$ Influenced by economist Thomas Sowell, Thomas served as Reagan's Assistant Secretary of Education for the Office of Civil Rights (U.S. Department of Education) between 1981 and 1982, before reluctantly joining the EEOC (1982-1990). He was nominated by George Bush at the Supreme Court in 1991, amid one of the first sexual harassment scandals in the US. Allegations were brought against him by attorney Anita Hill, a former colleague of him at the EEOC, whose interview with the FBI had leaked during the confirmation hearings of Thomas. His nomination was strongly opposed by Civil Rights activist and feminists; he is known as the most conservative member of the Supreme Court.

${ }^{64}$ Seven Supreme Court decision, but especially two in 1989, were especially crucial. In Price Waterhouse v. Hopkins, the courts rule an employer could escape liability if he can prove, even if plaintiff prove discrimination motivation, he would have taken the same decision based on lawful motives. In Wards Cove Packing Co. v. Antonio (1989), the court reversed the burden of proof, the plaintiff has to prove a lack of business necessity for the practice. The general interpretation is that these series of decision increase the challenge to prove discrimination for the plaintiff.

${ }^{65}$ The Act enforced disparate impact doctrine as it was originally formulated in Griggs.
} 
were always crucial to win a case. Or that they actually control all the aspects of the game in which they were engaged.

\section{CONCLUSION}

The Griggs decision has been interpreted by many scholars as having fostered the use of quantitative evidence in employment litigation. Indeed, changes in legislation as well as judicial decisions had a huge impact on the way MRA did or did not matter in the courts. But other developments were also crucial in the evolution and stabilization of the use of this type of economic analysis, including the operationalization of human capital, the development of personal computers, and the state and status of academic economics in the public sphere. Looking at how economics was used in courts provides a window into how economics was judged for its ability to provide clear-cut evidence outside academia. But it underlines also the way evidence in economics fits the rules of evidence in the courts and the implications for the social authority of this field.

This paper described the reception of economists' expert testimonies as recorded in decision as well as how economists reflected on their own practice; and how, in the mid-1980s, economists started to organize their market. The establishment of standards within social sciences as well as the rules of evidence admissibility are moving targets. In this paper, I showed how the interaction of these two aspects of expert testimony first met, confront and then adapt. This paper has four results. I first show that early rejections of some economists' results (e.g. James, Stastny) were usually based on matters of law that encapsulate different frameworks to make sense of human behaviors than the one of economists. It was not a challenge to the admissibility of the method but rather a matter of the weight given to the economist' analysis. Economists' reports and testimonies became more and more important in the determination of facts in the 
second half of the 1970s but never seem to have played a major role in the resolution of a lawsuit before the 1980s. Second, economists never had the monopoly on the use of quantitative methods, but a clear increase in their standing as expert occurred in the 1980s: I framed this rise using the significant decision in Vuyanich. More research is needed on the relative standing of economics in comparison to other social sciences in court proceedings, but economists can be said to have clearly entered the courtrooms in the 1980s. Third, the diversity of the reception is not completely at odds with the academic debates of the time. This diffusion of tools, consistent with histories of human capital, is central to the type of discussions that occurred in courts. When the method became widely used, there were no more discussion concerning the underlaying hypothesis, as it occurred in the first period. Rather, starting in the 1980s, the courts endorsed tools subject to "how well they were used", and did not endorse a specific interpretation of economic theory. The court settings serve as a context to unpack the choice of the experts and provide a more diverse image of the practices of the economists. The focus on the diffusion of tools move historiographical debates about what is external or internal to the evolution of economics towards the analysis of the social practice of sciences. The development of economists' expertise in courts is not only a question of supply (the economics profession with its theory and models) meeting a demand (courts in need of expertise) in a market in partial equilibrium, but rather a set of constant interactions captured by more complex (and simultaneous) dynamics. Finally, the court system and the broader legal and political contexts - and especially the conservative legal turn (Teles 2008)—played an important part in the diverging opinions in the courts.

Starting in the 1970s, as a result of the passing of legislation, the courts were asked to judge private companies' employment policies. In many cases, companies were moved (or forced) to rethink their hiring and job assignment policies to comply with new legislation mandating equal 
opportunity. Some economists, among others social scientists, stepped in the "numbers game" with a specific set of tools: this paper has told the story of how this tools eventually became part of the "judicial tool-box" of employment discrimination cases by the end of the 1980s. This story offers a narrative about the ambiguous impact of economists' practices and the challenges the use of economic knowledge poses outside academia, especially when it impacts the lives of individuals. 


\section{Appendixes}

\section{Appendix 1 Corpus}

This paper is based on the study of 55 cases occurring between 1971 and 1989. I used WestLaw keyword system (Civil Rights 78, Evidence k) and advanced search tools using keyword "expert witness" in conjunction with "employment discrimination". I then turned to cases books, essentially Schlei and Grossman $(1983,1985)$, who list the use of regression analysis in Federal Courts from the mid-1970s until 1985. Finally, I used the secondary literature. Of the final sample, I choose 26 cases with identifiable discussion on MRA and, most of the time, identifiable experts. As a matter of comparison, Fienberg (1982) found three occurrences before 1972. Using Lexis database, Rubinfeld (1985) found 26 occurrences between 1969 and 1984. Connolly (1991) conducted a quantitative analysis of the use of MRA in employment discrimination cases in Federal Courts between 1971 and 1991 and found 46 cases, she quotes 30 cases. The difference is my choice to look at decisions with lengthy discussion of the method and of the expert testimony, and not merely mention of MRA.

This has to be compared to the actual number of cases filed and cases that go to trial. Less than 350 employment discrimination cases were filled in 1970, to a peak at 9'000 suits filed in 1983. Between 1970 and 1989, employment discrimination litigations grew much faster $(+2166 \%)$ than general civil disputes (+125\%) (Donohue and Siegelman 1991, p.985-986). A more recent empirical analysis confirmed the growth of litigation for the same period, and the relative stagnation, around a bit less than 10'000 cases a year between 1983 and 1990, and the spectacular rise in litigation in the early 1990s (Berrey, Nelson \& Nielsen 2017, figure 2.1., p.41). Keep in mind that, according to Berrey et al.'s model of litigation outcomes, less than $30 \%$ of case filled went to trial, $2 \%$ of cases filed in Federal Courts led to a win by the plaintiff (p.61-64). 


\section{Appendix 2 List of Cases}

Table 1 Case list.

n.a. : not available; labor econ : professor or assistant professor of economics, specialist labor economics ; econ: professor or assistant professor of economics; stat: professor or assistant professor of statistics or mathematics, specialist statistics; soc: professor or assistant professor of sociology; psy: professor or assistant professor of psychology; indus psy: industrial or organizational psychologist; comp: academic computer scientist; consult: primarily consultant; hist: historian).

F.Suppl.: Federal Supplement (federal District Courts), F. 2d.: Federal Reporter second edition (federal Courts of Appeals); S. Ct. or U.S. : Supreme Court reporter; WL: unpublished decision from District Courts.

\begin{tabular}{llll}
\hline Date & Cases & $\begin{array}{c}\text { Expert witness } \\
\text { (Plaintiff) }\end{array}$ & $\begin{array}{l}\text { Expert witness } \\
\text { (Defendant) }\end{array}$ \\
\hline \hline 1973 & United States v. U.S. Steel, 371 & nihil & Joan Gustafson \\
& F. Supp. 1045 & Haworth (labor \\
& & econ), Charles \\
& & Haworth ${ }^{2}$ (labor \\
& & econ)
\end{tabular}


Development Laboratories,

(labor econ)

1976 WL 13321

1976

Mecklenburg v. Montana

Gilchrest (soc, stat) Tiarhrt (stat)

Board of Regents of Higher

Education, 1976 WL 687

1977

James v. Stockham Valve \&

n.a.

James Gwartney

Fittings Co., 559 F. 2d 310

(labor econ), Joan

Gustafson Haworth

(labor econ)

1977

Presseisen v. Swathmore, 442

John DeCani (stat)

Paul Meier (stat) and

F. Supp. 593

Gudmund Iversen

(stat)

1977

Smith v. Union Oil Company, Unquoted

David Freedman

1977 WL 77

(stat)

1978

Stastny v. Southern Bell, 458

Lonnie Keith (stat)

James Gwartney

F. Supp. 314

(labor econ)

1978

Kyriazi v. Western Electric

John Ullman (stat)

n.a.

Company, 461 F. Supp. 894

1978

Dickerson v. US Steel, 472 F.

Peter Haimes

Paul Meier (stat)

Supp. 1304

(“equal-employment Samuel Shapiro (stat)

opportunity

specialist”) 
Commonwealth of

Pennsylvania v. Local Union

542, IUOE, 469 F. Supp. 329
Michael Watcher

(labor econ) Lewis

Perl (econ consult)

Arthur Dempster

(stat)

Wanzer Drane (stat),

Michigan, 495 F. Supp. 1021 (comp), John Dwyer Wayne Ruther (econ)

(stat), Mark

Killingsworth (labor

econ), John Abowd

(labor econ)

1980

Vuyanich v. Republic National

Janice Madden

Judith Stoikov (labor

Bank, 505 F. Supp. 224

(labor econ), David

Morgan (comp)

John Spaulding

David Snyder (n.a.),

(stat), Francine Blau

Patrick Odell (stat)

(labor econ)

1981

Paxton v. Union National

Bank, 519 F. Supp. 136

John Fluker (n.a.)

(labor econ)

1981

Segar v. Civiletti, 508 F. Supp.

690

(labor econ),

Mahlon R.

B.C. Spradlin (stat)

Straszheim (econ),

James Outtz (indus

psy)

Martin Kurke (psy),

Wanzer Drane (stat),

econ consult), Ross

Stolzenberg (soc),

James Gwartney 
873

1983

McDowell v. Safeway Stores

Inc., 575 F. Supp. 1007

Coser v. Moore, 587 F.Supp. Mark R.

572

1983

1983

1984

1985

1985

Mark R.

Supp. 769

econ)

Authority, 704 F. 2d 613

F. Supp. 875
Straszheim (econ) Robert R. Hill (econ)

Alda Moore (n.a.), Finis Welch ${ }^{4}$ (labor

Richard Goldstein econ)

(econ consult),

Martin Mador

(comp, no Ph.D.)

Killingsworth (labor econ), Lillard (n.a.),

econ), Aboud (n.a.) Paul Meier (stat)

Edgar F. Borgotta

Educ of City of NY, $561 \mathrm{~F}$. Killingsworth (labor (soc, psy)

Eastland v. Tennessee valley $\quad$ Ireland (n.a.) Martin (n.a.)

EEOC v. IBM (International William E. Sedlacek James L. Medoff

Business Machines Corp.), 583 (stat), Michelson (labor econ)

(econ consult)

Chang v. University of Rhode Harriet Zellner

Bernard Siskin $^{3}$ (stat)

Island, 606 F. Supp. $1161 \quad$ (labor econ)

Penk v. Oregon State Board of Mary Gray (stat, Bernard Siskin ${ }^{3}$

Higher education, 1985 WL comp), Ramsey ～(stat), Paul Meier

25631

(stat), Barbara

(stat), Finis Welch ${ }^{4}$

Bergmann (labor (labor econ), Joan

econ) 
Gustafson Haworth ${ }^{2}$

(labor econ)

1986

Bazemore v. Friday, 106 S. Ct. Charles Mann

Francis Giesbrecht

3000

(stat)

1988

EEOC v. Sears, 628 F. Supp.

Bernard Siskin

Joan Gustafson

1264

(stat), Alice

Haworth (labor

Kessler-Harris (hist) econ), Rosalind

Rosenberg (hist)

1988

Ottaviani v. State University of

Mary Gray (stat)

Judith Stoikov (econ

New York at New Paltz, 679 F.

consult)

Supp. 288

Appendix 3 Statutes list

Civil Rights Act, 78 Stat. 241, 1964

Civil Rights Act, 105 Stat. 1071, 1991

Equal Employment Opportunity Act, 86 Stat. 103, 1972

\section{Appendix 4 Cases not included in Appendix 1}

Griggs v. Duke Power \& Co., 401 U.S. 424, 1971

McDonell Douglas Corp. v. Green, 411 U.S. 792, 1971

Loving v. Virginia, 988 U.S. 1, 1967

Price Waterhouse v. Hopkins, 490 U.S. 228, 1989

Wards Cove Packing Co. v. Antonio, 490 U.S. 642, 1989 


\section{References}

Abbot, Andrew. 1988. The System of Professions: An Essay on the Division of Expert Labor. Chicago: University of Chicago Press.

Arrow, Kenneth J. 1972. “Models of Job Discrimination.” In Anthony H. Pascal, editor, Racial Discrimination in Economic Life. New York, NY: Lexington Books, pp- 83-102.

Arrow, K. J. 1973. "Higher Education As A Filter.” Journal of Public Economics, 2 (3): 193216.

Ash, Elliott, Daniel L. Chen, and Suresh Naidu. 2018. "Ideas Have Consequences: The Impact of Law and Economics on American Justice.” Working paper.

Ashenfelter, Orley C. and David E. Bloom. 1984. "Models of Arbitrator Behavior: Theory and Evidence. American Economic Review." 74 (1): 111-124.

Ashenfelter, Orley C. and Ronald L. Oaxaca, 1987. "The Economics of Discrimination: Economists Enter the Courtroom.” American Economic Review, 77 (2): 321-25.

Backhouse, Roger and Béatrice Cherrier. 2017a. "The Age of the Applied Economist: The Transformation of Economics since the 1970s." History of Political Economy, 49 (supplement): $1-33$.

Backhouse, Roger and Béatrice Cherrier. 2017b. “'It’s Computers, Stupid!' The Spread and the and the Changing Roles of Theoretical and Applied Economics." History of Political Economy, 
49 (supplement): 103-126.

Becker, Gary S. 1964. Human Capital: A Theoretical and Empirical Analysis, with special Reference to Education. New York: Columbia University Press.

Becker, Gary S. [1957] 1971. The Economics of Discrimination. Chicago: The University of Chicago Press.

Becker, Gary S. 1976. The Economic Approach to Human Behavior. Chicago: The University of Chicago Press.

Bergmann, Barbara. 1986. The Economic Emergence of Women. New York, NY: Basic Books.

Bergmann, Barbara. 1989. “Does the Market for Women’s Labor Need Fixing?” The Journal of Economic Perspectives, 3 (1): 43-60.

Berrey, Ellen, Robert L. Nelson and Laura Beth Nielsen. 2017. Rights on Trials. How Workplace Discrimination Law Perpetuates Inequality. Chicago: The University of Chicago Press.

Blau, Francine D. 1977. Equal Pay in the Office. Lexington, Mass.: Lexington Books.

Blau, Francine D. 1984. “Discrimination Against Women: Theory and Evidence.” In William A. Darity, Jr., ed., Labor Economics: Modern Views, Boston: Kluwer-Nijhoff, pp. 53-89. 
Blau, Francine D. and Marianne A. Ferber. 1987. "Discrimination: Empirical Evidence from the United States.” American Economic Review, 77 (2): 316-320.

Blau, Francine and Lawrence Kahn. 2017. "The Gender Wage Gap: Extent, Trends, and Sources.” Journal of Economic Literature. 55 (3): 789-865.

Blaug, Mark. 1976. "The Empirical Status of Human Capital Theory: A Slightly Jaundiced Survey." Journal of Economic Literature, 14 (3): 827-855.

Blinder, Alan S. 1973. "Wage Discrimination: Reduced Form and Structural Estimates." Journal of Human Resources, 8 (4): 436-455.

Bloom, David E. and Mark R. Killingsworth. 1982. "Pay Discrimination Research and Litigation: The Use of Regression.” Industrial Relations, 21 (3): 318-339.

Brandmayr, Federico. 2017. "How Social Scientists Make Causal Claims in Court: Evidence from the L'Aquila Trial.” Science, Technology, \& Human Values, 42 (3): 346-380.

Breslau, Daniel. 1997. “The Political Power of Research Methods: Knowledge Regimes in US Labor Market Policy.” Theory and Society, 26 (6): 869-902.

Brookshire, Michael L. 2003. "A History of the National Association of Forensic Economics, 1986-2001." Litigation Economic Review, 6 (1): 22-32.

Butler, Henry N. 1999. "The Manne Programs in Economics For Federal Judges.” Case 
Western Reserve Law Review, 50: 351-420.

Cain, Glen G. 1976. “The Challenge of Segmented Labor Market Theories to Orthodox Theory: A Survey." Journal of Economic Literature, 14 (4): 1215-1257.

Cain, Glen G. 1986. The Economic Analysis of Labor Market Discrimination: A Survey. University of Wisconsin-Madison, Institute for Research on Poverty.

Camic, Charles, Neil Gross and Michèle Lamont, eds. 2011. Social Knowledge in the Making. Chicago, IL: Chicago Unievrsity Press.

Chassonnery-Zaïgouche, Cléo. 2019. “Setting Rational Wages? Economists' Arguments in the Comparable Worth Controversy, 1979-1989.” Working Paper.

Cherrier, Béatrice. 2009. Valeurs et théorisation économique chez Gunnar Myrdal, Jacob Marschak, et Milton Friedman. Ph.D. Thesis, University Paris X Nanterre.

Cherrier, Béatrice. 2008. "Toward a History of Economics at MIT, 1940-72." History of Political Economy, 46 (supplement): 15-44.

Cherrier, Béatrice. 2017. "Classifying Economics: A History of the JEL Codes." Journal of Economic Literature, 55 (2): 545-579.

Cohen, Lloyd R. and Joshua D. Wright (eds.). 2011. Pioneers of Law and Economics. Cheltenham, UK: Edward Elgar. 
Connolly, Catherine. 1991. "The Use of Multiple Regression Analysis in Employment Discrimination Cases." Population Research and Policy Review. 10 (2): 117-135.

CSWEP. 1992. "Biographical Sketches of CSWEP Members. Joan Gustafson Haworth." CSWEP Newsletter, February 1992, 1-36.

Dempster, Arthur. 1988. "Employment discrimination and statistical Science." Statistical Science 3 (2): 149-195.

Dobbins, Frank. 2009. Inventing Equal Opportunity. Princeton, NJ: Princeton University Press.

Donohue III, John J. and Peter Siegelman. 1991. "The Changing Nature of Employment Discrimination Litigation.”Stanford Law Review, 43 (5): 983-1033.

Donohue III, John J. and James J. Heckman. 1991. “Continuous Versus Episodic Change: The Impact of Civil Rights Policy on the Economic Status of Blacks." Journal of Economic Literature, 29 (4): 1603-1643.

Dow, Steven B. 2004. “There's Madness in the Method: A Commentary on Law, Statistics, and the Nature of Legal Education." Oklahoma Law Review, 57 (3): 579-599.

Duarte, Pedro Garcia. 2014. "The Early Years of MIT PhD Program in Industrial Economics." History of Political Economy, 46 (Annual Supplement): 81-108. 
Ehrenberg, Ronald G. and Robert S. Smith. 1983. "Economic and Statistical Analysis of Discrimination in Hiring." NBER Working Paper no. 1222, 1-17.

Figart, Deborah M. and Ellen Mutari. 2005. "Rereading Becker: Contextualizing the Development of Discrimination Theory.” Journal of Economic Issues, 39 (2): 475-483.

Fienberg, Stephen E. 1982. "Comment: The Increasing Sophistication of Statistical Assessments as Evidence in Discrimination Litigation." American Statistical Association Journal, 77(380): 784-787.

Fienberg, Stephen E. (ed.). 1989. The Evolving Role of Statistical Assessments as Evidence in the Courts. New York and Berlin: Springer-Verlag. Original edition: Report of the Panel on Statistical Assessments as Evidence in Court, Steven E. Fienberg ed., Washington, D.C.: National Academy Press, 1989.

Finkelstein, Michael O. 1966. "The Application of Statistical Decision Theory to the Jury Discrimination Cases." Harvard Law Review, 80 (2): 338-376.

Finkelstein, Michael O. 1973. "Regression Models in Administrative Proceedings." Harvard Law Review, 86 (8): 1442-1475.

Finkelstein, Michael O. 1980. “The Judicial Reception of Multiple Regression Studies in Race and Sex Discrimination Cases." Columbia Law Review, 80 (4): 737-754.

Fisher, Franklin M. 1958. "The Mathematical Analysis of Supreme Court Decisions: The Use and Abuse of Quantitative Methods.” American Political Science Review, 52 (2): 321-338. 
Fisher, Franklin M. 1980. "Multiple Regression in Legal Proceedings.” Columbia Law Review, 80 (4): 702-736.

Fisher, Franklin M. 1986. "Statisticians, Econometricians, and Adversary Proceedings." Journal of the American Statistical Association, 81 (394): 277-286.

Fisher, Franklin M. 1988. "Employment Discrimination and Statistical Science: Comment." Statistical Science, 3 (2): 161-165.

Fisher, Franklin M. 1990. "Book Review of The Evolving Role of Statistical Assessments as Evidence in the Courts, by Stephen E. Fienberg." Journal of Economic Literature, 28 (3): 12421243

Fourcade, Marion, Etienne Ollion and Yann Algan. 2015. "The Superiority of Economists." Journal of Economic Perspectives, 29 (1): 89-114.

Fourcade, Marion. 2018. "Economics: The View from Below." Swiss Journal of Economics and Statistics, 154 (1): 5-14.

Gieryn, Thomas F. 1983. "Boundary-Work and the Demarcation of Science from Non-Science: Strains and Interests in Professional ideologies of Scientists." American Sociological Review, 48 (6): 781-795. 
Gustafson Haworth, Joan C. and Charles T. Haworth. 1976. "Statistical Inference in Civil Rights Decisions." Proceedings of the American Statistical Association, Social Sciences Section, Part I, 47-52.

Gustafson Haworth, Joan C., James Gwartney and Charles T. Haworth. 1975. "Earnings, Productivity, and Changes in Employment Discrimination During the 1960s." American Economic Review, 65 (1): 158-168.

Goldberg, Matthew S. 1982. "Discrimination, Nepotism, and Long-Run Wage Differentials." Quarterly Journal of Economics, 97 (2): 307-319.

Golan, Tal. 1999. "Revisiting the History of Scientific Expert Testimony." Brooklyn Law Review, 73 (3): 879-942.

Green, Craig. 2009. “An Intellectual History of Judicial Activism.” Emory Law Journal, 58 (5): 1195-1264.

Gwartney, James, Ephraim Asher, Charles T. Haworth and Joan C. [Gustafson] Haworth. 1979. "Statistics, the Law and Title VII: An Economist's View." Notre Dame Law Review, 54 (1): 633-660.

Harnay, Sophie and Alain Marciano. 2009. "Posner, Economics and the Law: From Law and Economics to an Economic Analysis of Law." Journal of the History of Economic Thought, 31 (2): 215-232.

Haskell, Thomas and Sanford Levinson. 1988. “Academic Freedom and Expert Witnessing: Historians and the Sears Case.” Texas Law Review, 66: 1629-1659. 
Heckman, James J., Lance J. Lochner, and Petra E. Todd. 2003. "Fifty Years of Mincer Earnings Regressions.” NBER Working Paper No. 9732, 1-73.

Holden, Laura and Jeff Biddle. 2017. "The Introduction of Human Capital Theory into Education Policy in the United States." History of Political Economy, 49 (4): 537-574.

Jasanoff, Sheila. 1995. Science at the Bar. Law, Science, and Technology in America. Cambridge, MA: Cambridge University Press.

Jasanoff, Sheila. 1992. "What Judges Should Know About the Sociology of Science." Jurimetrics, 32 (3): 345-359.

Jellison Katherine. 1987. "History in the Courtroom: The Sears Case in Perspective." The Public Historian. 9 (4): 9-19.

Jenkins, Pamela J. and Steve Kroll-Smith. 1996. Witnessing for Sociology: Sociologist in Court. Wesport, CT: Praeger.

Johnston, Jack. 1972. Econometrics Methods. New York City (NY): McGraw-Hill Inc. 1963, 1971, 1978.

Kaye, David H. 1982a. "Evidence of Discrimination." Journal of the American Statistical Association, 77 (380): 773-783. 
Kaye, David H. 1982b. "The Numbers Game: Statistical Inference in Discrimination cases. Reviewed work: Statistical proof of Discrimination by David Baldus and James Cole." Michigan Law Review, 80 (4): 833-856.

Kaye, David H. 1990. "Improving Legal Statistics. Review essay of Statistics and the Law by Morris Degroot, Stephen E. Fienberg and Joseph B. Kadane; The Evolving Role of Statistical Assessments as Evidence in the Courts by Stephen E. Fienberg." Law \& Society Review, 24 (5): $1255-1276$

Kessler-Harris, Alice. 1988. "Academic Freedom and Expert Witnessing: A Response to Haskell and Levinson." Texas Law Review, 67: 429-440.

Killingsworth, Mark R. 1993. "Analyzing Employment Discrimination: From the Seminar Room to the Courtroom." American Economic Review, 83 (2): 67-72.

Kmenta, Jan. 1971. Elements of Econometrics. New York City, NY: Macmillan. 1986

Latour, Bruno. 2010. The Making of Law. An Ethnography of the Conseil d'État. Translated by Marina Brilman and Alain Pottage. Cambridge, UK: Polity Press.

Lawson, Robert A. 2014. “Freedom as Development: Reflections on James Gwartney's Contributions to Measuring Institutions.” In Joshua C. Hall (ed), The Annual Proceedings of the Wealth and Well-Being of Nations 2013-2014, Beloit, WI: Beloit College Press.

Lundberg, Shelly J. and Richard Startz. 1983. "Private Discrimination and Social Intervention in Competitive Labor Market.” American Economic Review,73 (3): 340-347. 
Lynch, Michael and Ruth McNally. 1999. "Science, Common Sense and Common Law: Courtroom Inquiries and the Public Understanding of Science." Social Epistemology, 13 (2): 183-196.

Maddala, Gangadharrao Soundalyarao “G. S”. 1977. Econometrics. New York City, NY: McGraw-Hill Inc.

Madden, Janice Fanning. 1973. The Economics of Sex Discrimination. Lexington, Mass.: D.C. Heath and Company.

Madden, Janice Fanning. 1987. "Review of Comparable Worth.” Journal of Policy Analysis and Management, 7 (1): 147-150.

Mandel, Michael J. 1999. "Going for the Gold: Economists as Expert Witnesses." Journal of Economic Perspectives, 13 (2): 113-120.

Marshall, Ray. 1974. "The Economics of Racial Discrimination: A Survey." Journal of Economic Literature, 12 (3): 849-871.

Meier, Paul, J. Sacks and S. Zabell. "What Happened in Hazelwood: Statistics, Employment Discrimination, and the 80\% Rule." American Bar Foundation Research Journal, 9 (1): 139186.

Meier, Paul. 1986. "Damned Liars and Expert Witnesses." Journal of the American Statistical Association, 81 (394): 269-276. 
Medema, Steven G. 2018. "Scientific imperialism or Merely Boundary Crossing? Economists, Lawyers, and the Coase Theorem at the Dawn of the Economic Analysis of Law." In Uskali Mäki, Adrian Walsh and Manuela Fernández Pinto, eds, Scientific Imperialism. Another Facet of Interdisciplinarity. Abington: Routledge.

Mercuro, Nicholas and Steven G. Medema. 2006. Economics and the Law. From Posner to Post-Modernism and Beyond. Princeton, NJ: Princeton University Press.

Mincer, Jacob. 1974. Schooling, Experience, and Earnings. New York: NBER Book, Columbia University Press.

Note. 1975. "Beyond the Prima Facie Case in Employment Discrimination Law: Statistical Proof and Rebuttal." Harvard Law Review, 89 (2): 387-422

Oaxaca, Ronald L. 1973. "Male-Female Wage Differentials in Urban Labor Markets." International Economic Review, 14 (3):693-709.

Oaxaca, Ronald L. 2007. "The Challenge of Measuring Labor Market Discrimination Against Women." Swedish Economic Policy Review, 14 (1): 199-231.

Panhans, Matthew T. and John D. Singleton. 2017. “The Empirical Economist's Toolkit: From Models to Methods." History of Political Economy, 49 (supplement): 127-157. 
Pedriana, Nicholas, and Robin Stryker. 1997. "Political Culture Wars 1960s Style: Equal Employment Opportunity, Affirmative Action and the Philadelphia Plan." American Journal of Sociology, 103: 633-691.

Pedriana, Nicholas, and Robin Stryker. 2004. "The Strength of a Weak Agency: Title VII of the Civil Rights Act and Expansion of State Capacity, 1965-1971." American Journal of Sociology, 110: 709-760.

Pindyck, Robert S. and Daniel L. Rubinfeld. 1976. Econometric Model and Economic Forecast. New York City (NY): McGraw-Hill Inc. 1981. 1991. 1998. 2000.

Pindyck, Robert S. and Daniel L. Rubinfeld. 1989. Microeconomics. 1992, 1995, 1998, 2001, 2005, 2009, 2013, 2017.

Phelps, Edmund S. 1972. "The Statistical Theory of Racism and Sexism.” American Economic Review, 62 (4): 659-661.

Posner, Richard A. 1999. "The Law and Economics of the Economic Expert Witness." Journal of Economic Perspectives, 13 (2): 91-99.

Remick, Helen. 1981. "The Comparable Worth Controversy.” Public Personnel Management Journal. 10 (4): 371-383.

Renfro, C.G. 2004. "Econometric software: The first fifty years in perspective." Journal of Economic and Social Measurement, 29 (1-3): 9-107. 
Riach, P. A. and Rich, J. 1991. "Measuring Discrimination By Direct Experimental Methods: Seeking Gunsmoke.” Journal of Post Keynesian Economics, 14 (2): 143-150.

Rubinfeld, Daniel L. 1985. "Econometrics in the Courtroom." Columbia Law Review, 85 (5): 1048-1097.

Samuels, Warren J. 1992. "Ideology in Economics." In W. J. Samuels, Essays on the Methodology and Discourse of Economics. London: MacMillan, pp. 233-248.

Samuelson, Paul A. 1980. Economics. New York: MacGraw-Hill.

Sawhill, Isabel V. 1973. "The Economics of Discrimination Against Women: Some New Findings." Journal of Human Resources, 8 (3): 383-396.

Schlei Lindermann, Barbara and Paul Grossman, eds. 1983. Employment Discrimination Law. Three volumes. Washington, D.C.: American Bar Association, Section of Labor and Employment Law, The Bureau of National Affairs.

Schmelzer, Matthias. 2016. The Hegemony of Growth. The OECD and the Making of the Economic Growth Paradigm. Cambridge, UK: Cambridge University press.

Shapin, Steven. 1995. "Cordelia's Love: Credibility and the Social Studies of Science. Perspectives on Science, 3 (3): 255-275. 
Spence, Michael 1973. “Job Market Signaling.” Quarterly Journal of Economics, 87 (3): 355374.

Steenken, Beau and Tina M. Brooks. 2015 Sources of American Law. An Introduction to Legal Research. Center for Computer-Assisted Legal Instruction eLangdell Press [online open edition, url: http://elangdell.cali.org].

Stryker, Robin. 2011. "L'intermédiation scientifique dans la mise en œuvre des lois antidiscrimination américaines. " In C. Bessy, T. Delpeuch and J. Pélisse, eds., Droit et régulation des activités économiques. Perspectives sociologiques et institutionnalistes, pp. 183-202.

Stryker, Robin, Danielle Docka-Filipek, and Pamela Wald. 2012. "Employment Discrimination, Law and Industrial Psychology: Social Science as Social Authority and the CoProduction of Law and Science.” Law \& Social Inquiry, 37 (4): 777-814.

Svorenčík, Andrej. 2014. "MIT’s Rise to Prominence: Outline of a Collective Biography." History of Political Economy, 46 (Annual supplement): 109-133.

Teixeira, Pedro N. 2018. "Conquering or Mapping? Textbooks and the Dissemination of Human Capital Theory in Applied Economics." The European Journal of the History of Economic Thought, 25 (1): 106-133.

Teixeira, Pedro N. 2017. "Economic Beliefs and Institutional Politics: Human Capital Theory and the Changing Views of the World Bank About Education (1950-1985)." The European Journal of Economic Thought, 24 (3): 465-492. 
Teixeira, Pedro N. 2007. Jacob Mincer: A Founding Father of Modern Labor Economics. Oxford: Oxford University Press.

Teles, Steven M. 2008. The Rise of the Conservative Legal Movement. The Battle for Control of the Law. Princeton, NJ: Princeton University Press.

Thornton, R. and Ward, J. 1999. “The Economist in Tort Litigation.” Journal of Economic Perspectives, 13 (2): 101-112.

Turk, Katherine. 2016. Equality on Trial. Gender and Rights in the Modern American Workplace. Philadelphia: University of Pennsylvania Press.

Wonnacott, Ronald J. and Thomas H. Wonnacott. 1979. Econometrics (Probability and Mathematical Statistics). Hoboken (NJ): John Wiley and Sons. 1970, 1971.

Wallace, Phyllis A., ed. 1976. Equal Employment Opportunity and the AT\&T Case. Cambridge, MA: MIT Press. 